NBER WORKING PAPER SERIES

COMPUTERS, WORK ORGANIZATION, AND WAGE OUTCOMES

\author{
Peter Cappelli \\ William Carter
}

Working Paper 7987

http://www.nber.org/papers/w7987

\author{
NATIONAL BUREAU OF ECONOMIC RESEARCH \\ 1050 Massachusetts Avenue \\ Cambridge, MA 02138 \\ October 2000
}

The data used in this analysis were collected with support from the Education Research and Development Center program, agreement number R117Q00011-91, CFDA 84.117Q, as administered by the Office of Educational Research and Improvement, U.S. Department of Education. The research was conducted while Carter was a research associate at the Center for Economic Studies, U.S. Bureau of the Census, with financial support from the National Center for Post-Secondary Improvement. The findings and opinions expressed in this paper do not necessarily reflect the position or policies of OERI, the U.S. Department of Education, the Bureau of the Census, the NBER, or the Center for Economic Studies. Thanks to Arnie Reznek at the Bureau of the Census for help with the data project and to participants at the MIT Industrial Relations Seminar, Colgate/Hamilton Economics Seminar, and the Jerome Levy Economics Institute Workshop on Earnings Inequality for helpful comments.

(C) 2000 by Peter Cappelli and William Carter. All rights reserved. Short sections of text, not to exceed two paragraphs, may be quoted without explicit permission provided that full credit, including $@$ notice, is given to the source. 
Computers, Work Organization, and Wage Outcomes

Peter Cappelli and William Carter

NBER Working Paper No. 7987

October 2000

JEL No. J3

\begin{abstract}
We examine two factors frequently thought to be changing the U.S. workplace, high performance work practices and computer use, and their relationships with pay using a national probability sample of U.S. establishments. The analysis controls for both organizational and individual characteristics and finds that higher wages are associated with several practices, particularly computer use and teamwork, for front-line workers who are the targets of most high performance work practices. Not surprisingly, relationships are not as strong for other occupations and are very weak in the non-manufacturing sector. Computer use is a particularly important influence on the wages of managers and supervisors, although it is computer use by their subordinates that is the important factor. The most unusual result may be the consistently negative and significant relationship between wages and job rotation where additional analyses suggest that job rotation in isolation from other high performance practices may proxy lower skill jobs. Some of the positive relationships vanish when various controls for human capital are added, suggesting that those wage premiums are a return to human capital and may be driven by greater skill requirements.
\end{abstract}

Peter Cappelli

Center for Human Resources

308 Vance Hall

3733 Spruce Street

Philadelphia, PA 19104-6358

and NBER

cappelli@wharton.upenn.edu 


\section{Computers, Work Organization, and Wage Outcomes}

Studies of wage determination have long been a central theme in research on employment across the social sciences, and the interest in this topic increased considerably with efforts to understand the growth in income inequality (Levy and Murnane 1992; Danzinger and Gottschalk 1994). In labor economics where theories of wage determination have been a primary topic, the focus of empirical work has been on the individual worker and their job, the "supply" part of the market equation. At least in part, as Leonard, Mulkay, and Audenrode (1999) argue, the focus on supply was because data were available for individuals but not for firms. More recently, the availability of data on employers has renewed interest in the effects that their practices have on labor demand and, in turn, on wage determination.

With respect to those practices, labor economics and economics in general has devoted considerable attention in recent years to the effect of technology, especially computers, on labor market outcomes (see below). Industrial Relations and Human Resources, on the other hand, have focused attention on innovative work systems such as those labeled as "high performance" systems (see below). Recent research suggests that computer use and innovative work systems covary and may be part of a common strategy of innovation in organizations (Leigh and Gifford 1999; Seigel 1999; Bresnahan et al.1999), which suggests the importance of examining them together.

There are many theories of wage determination and several with special relevance to how changes in jobs might affect pay. For example, human capital theory predicts that higher wages may represent, among other things, a return to prior investments in scarce skills, so that rising wages result when changes in jobs make greater demands on these scarce skills. Compensating differential theory predicts that when jobs change in ways that require more effort or that otherwise reduce utility, pay will rise to compensate for that effort. Efficiency wage theory predicts that if jobs change in ways that require higher levels of diligence and compliance with rules (or alternatively, lower levels of shirking), employers will pay a premium to help ensure that diligence.1

These theoretical arguments about relationships between practices like computer use or innovative work practices and pay typically begin with the assumption that the innovations change job requirements in some fundamental way. But the problem is in knowing exactly what those changes are. We often think of work with computers as raising skill requirements, for example, but many computer-assisted tasks, such as word processing, make tasks easier. Similarly, work practices like teamwork may demand more skills from employees than previous arrangements, but the skills they demand - such as interpersonal skills -- may be

11 Summaries of these theories can be found in Ashenfelter and Card (1999). 
in ready supply and therefore not bid up wages. The new tasks may even be ones that employees enjoy, suggesting that the changes might even work to reduce pay. Finally, even if these practices do not draw on scarce skills or require a compensating differential in the usual sense, they may increase the importance of the tasks that workers are performing or the importance of difficult to monitor effort or diligence in the performance of tasks, suggesting a different motivation for pay premiums.

The next two sections review in detail the empirical evidence about how the use of computer technology and innovative work systems, respectively, affect job requirements. A reasonable conclusion is that we do not know enough yet to be certain about how either changes jobs, specifically individual jobs. Without greater certainty, it is difficult to know which theories are most appropriate for explaining the relationships between computer use, work systems, and pay. One option might be to wait until other research reaches a consensus about how these innovations affect jobs and use that consensus to motivate hypotheses about pay. The other alternative, pursued below, is to treat the relationship between these innovations and wages as an empirical question and then to use the results to draw inferences about how these innovations are changing job requirements.

\section{RESEARCH ON TECHNOLOGY}

There is a long literature in the social sciences exploring how technology drives job requirements. Often the word "technology" was used to refer to broad changes in production systems, such as the industrial revolution or the factory system. One line of research argues that technological change has tended to increase skill requirements by eliminating noxious physical labor. Its focus is on technological changes that are so massive and inexorable, such as industrialization, that their effects on employment can be treated as exogenous for an individual employer.2 Contemporary research on skill-biased technological change essentially makes this same argument, that production functions are changing in ways that raise skill requirements (e.g., Bound and Johnson 1992; Behrman, Bound, and Griliches 1994).

Another, and perhaps equally long tradition, sees technological change operating to reduce the breadth of skills required from workers and, in particular, their control over the way jobs are performed. ${ }^{3}$ The

2 Arguments about the benefits to workers of technology began with Adam Smith, then with the scientific socialists, and continued in studies of economic development. Kerr and coworkers (1960), for example, saw industrialization as liberating production workers and leading to more skilled jobs. Students of industrial technology such as Woodward (1965) argued that assembly line work was only a stop on the road toward automated, "continuous production" factories where workers would be freed from machine-paced tasks. Blauner (1964) argued that such technologies would actually lead to an increase in skill, for example, as workers performed a broader range of monitoring tasks. This thesis reaches its high point with Bell's (1973) arguments that knowledge-based jobs would replace production work in the economy of the future.

3 Adam Smith's observations about the increasing division of labor and the narrowing of jobs that results can also be seen as part of the beginning of the deskilling argument. Durkheim (1964), Veblin (1914) and others were concerned about the dehumanizing effects of automation and factory production and the broader effects it would 
"deskilling" research reached its peak in the 1970s (e.g., Marglin (1974) and Braverman (1974)). It focused on changes within individual jobs, as opposed to across jobs, and relied on forces internal to the firm, such as management strategies for raising the supply of available workers, for its explanations (see Attewell 1990 for a review).

Yet another, more eclectic approach asserts explicitly that technology is a choice variable and that the effect on skill, and ultimately on wages, may go in either direction.4 This middle position assumes that situational factors such as labor costs or employee bargaining power are important in determining the utility of any technology or system of work organization. Many of these studies suggest that while technology was certainly affecting skill requirements, any increases were unlikely to be dramatic. ${ }^{5}$

A related body of research focuses on the complimentarity between skills and firm technology choices. Historical research finds that as early as the 1920 s, more technologically sophisticated firms hired more educated workers (Goldin and Katz 1995). Research on contemporary practices (Bartel and Sicherman 1995) finds a similar result, that technological change increases training within firms. Berndt and Morrison (1991) find that investments in certain kinds of capital (mainly office equipment) are associated with increased education among production workers and a shift toward presumably more highly skilled non-production workers. Berman, Bound, and Griliches (1994) argue that the level and rate of change in computer investments for manufacturing firms is a good proxy for their overall technological change and explains the shift toward higher skilled workers in some operations. Levy and Murnane (1996) find that computer use is associated with higher levels of specific skills as does Bresnahan et al. (1999) (although other studies suggest that higher skills

have on society. Scientific management as a theoretical argument for deskilling and of assembly line production methods in basic industries led to widespread acceptance of the deskilling argument supported by research findings (Walker and Guest 1952; Bright 1966) and to a shift in research to examine the consequences of deskilled jobs (e.g.,Blauner 1964).

4 Most of these studies are cases, and many are historical. Hobsbawm (1964) describes, for example, how craft workers were able to use the techniques of organized labor (e.g., controlling supply) to resist management efforts to deskill jobs. Edwards, Reich, and Gordon (1979) suggest that changes in skill have been the result of a complex process of bargaining between management and labor. Flynn's (1988) survey of hundreds of case studies of technological change finds considerable variance in the effects on employment and skill levels, lending support to the "mixed effects" hypothesis.

5 Other studies in this period continued to emphasize the relationship between technology and skill. Hirshhorn (1984) suggests an argument similar to Bell's (1973) that new automated technologies will require higher-order mental and social skills from workers. Studies of the introduction of numerically controlled production machinery have suggested that the introduction of these machines is designed to reduce worker's skill (Noble 1977). Further, even where the mix of skills associated with numerically controlled jobs appears to grow, the changes may simply add more boring tasks and leave the content of the jobs degraded (Adler 1986). Studies in the "mixed result/it depends" tradition report a variety of changes in skill across situations, depending typically on contextual issues. (See the papers in Hyman and Streek [1988] and Zuboff [1988] for case-based examples and Kelley [1989] for a survey-based argument.) Overall, a National Academy of Sciences study (Cyert and Mowery 1987) concluded that changing technology was unlikely to increase skill requirements during the immediate future. (See Levin et al. 1990 for a similar conclusion.) 
may be leading to new technology). ${ }^{6}$ While these studies do not attempt to explain the structure of wages, the clear implication is that technology should be associated with higher wage levels, at least for the same job, because it seems to require more educated, better trained, and higher skilled employees.

Several studies have attempted to see how these technology choices, broadly defined, affect wage outcomes. Mincer (1991) offers one of the first studies to argue that technology, broadly defined, explains some of the increase in the returns to education over time. Bound and Johnson (1992) compare different explanations for changes in the overall structure of wages in the 1980s using changes in education levels of workers as a proxy for technology. They conclude that technology change, again broadly defined, was the most important factor in explaining changes in wage premiums in this period.

More recently, computer technology has become the focus of attention as to the forces driving increases in the demand for skill. Analyses report, for example, that computer use explains as much as a third of the increased return to education in the 1980s (Krueger 1993), that the use of advanced production technologies in manufacturing (which may be correlated with computer use) is associated with higher wages for both production and non-production workers (Dunne and Schmitz (1993), that the increase in computer usage explains a large part of skill deepening and rising wages (Autor, Katz, and Krueger 1997), and finally, that perhaps computers are a proxy for other factors that affect wages, such as unobserved characteristics of jobs and human capital (DiNardo and Pischke 1997). ${ }^{7}$ Alternative methods of controlling for these unobserved factors using a sample of identical twins finds no significant increase in earnings associated with computer use (Krashinshy 2000).

\section{RESEARCH ON WORK ORGANIZATION}

As noted earlier, an important focus of research in industrial relations and human resources over the past decade has been the introduction of innovative work systems. This interest developed because of the view that these practices might offer benefits both to employees, in terms of more satisfying work, and organizations, in terms of improved performance (see Cotton 1993 and Appelbaum and Batt 1994 for surveys

\footnotetext{
${ }^{6}$ Bartel and Lichtenberg (1987), for example, find that operations with more educated workers adopt new technologies sooner and that the decision to adopt new systems then increases further the demand for skill. Doms, Dunne, and Troske (1997) find that plants with more educated workers adopt more sophisticated technology, not that the technology leads to a more educated workforce.

7 Mishel and Bernstein (1994) question whether the conclusion can really be drawn that technological change, however defined, can explain changes in wage differentials during the 1980s. They argue that research showing relationships between technology and wages -- that is, between levels -- does not explain changes in wage differentials. In order to do the latter, one needs to show that there has been a change in technology; specifically, that the rate of introduction of technology was somehow greater in the 1980s. And, as noted earlier, the evidence does not suggest that this was the case. Indeed, the pace of change may even have declined somewhat (Howell and Wolf 1991).
} 
of hundreds of articles on the effects of these systems).

The contemporary debate about these new models of work in the U.S. began by identifying "high performance" (HP) work systems in the context of new production systems: high performance production systems were those that seemed to generate higher levels of output, and the work systems demanded by them were identified, by definition, as high performance work. These production systems are most clearly associated with Japanese manufacturing and include techniques such as statistical process control, just-in-time inventory systems (JIT), continuous improvement, and total quality management (e.g., National Academy of Sciences 1986). The new work systems were driven by a series of specific work practices such as employee empowerment or participation in decision making where employees take over some tasks previously performed by supervisors, engineers, and staff specialists; Teamwork where autonomous or semi-autonomous teams take over some direct supervision and substitute for formal management structures; Job rotation/cross training where employees within teams swap tasks and become more interchangeable; Total Quality Management (TQM) where work groups take over responsibility for many of the factors affecting product quality.

The next step in research was to examine how these systems affected organizational performance. Quality circles, for example, were associated with increased productivity (Katz, et al.1983; Katz et al. 1985). Perhaps the most influential research stemming from this interest was the International Motor Vehicle Project at MIT, which provided evidence of the superiority of Japanese assembly plant operations, in terms of quality and productivity, as compared with other producers (Womack, Jones, and Roos, 1990; MacDuffie 1996). More recent studies followed and focused on productivity-related performance measures. Ichniowski, et al. (1997), for example, found that the introduction of "innovative work practices," among which are included teams and incentive pay, were associated with higher worker productivity, and that combinations of these practices yielded additional productivity improvements. Other studies examined the relationships between these practices and individual performance and found more nuanced conclusions. Cappelli and Rogovsky (1998) find that employee performance in a sample of public utilities is higher where employees are involved in decisions affecting work and individual tasks but is no higher where they are involved in decisions governing the terms and conditions of employment. Batt (1999) compares the sales of call center employees operating under traditional, mass production work systems to those using TQM systems and self-directed teams. She finds higher performance associated with self-directed teams but no performance effects associated with TQM systems.

The models of high performance work systems basically argue that increased quality, productivity, and flexibility can be obtained by making better use of employees. These arrangements demand significantly more from employees than do work systems associated with scientific management where tasks are narrowed and virtually all decision-making is in the hands of management. 
Advocates of these changes sometimes assume that they raise skill requirements and that the upgrading of skills, in turn, should be associated with higher wages (National Center 1990; Office of Technology Assessment 1990). But, thinking back to general theories about wages, it is not known whether these practices demand more of the skills that are in any sense scarce or simply make greater use of common skills that have been underused before. Nor is it clear whether the greater "effort" that these systems requires compensation given the body of research on "job enrichment," which suggests that workers are more satisfied with jobs that have these arrangements (see Cotton 1993). There is even some evidence that they raise satisfaction with pay (Cappelli and Sherer 1989), implying that workers might even be willing to work for lower wages where these practices are present.

Further, new work arrangements such as teamwork and job rotation seem to raise skill demands primarily for behavioral and interpersonal skills like the ability to get along with others and work in teams. These skills that may be difficult to identify and credential and may only be observed in the context of doing actual jobs. Because other employers cannot identify them, it may be more accurate to think of these skills as specific to the firm and not ones that necessarily generate higher market wages.

Even if the above arguments were true, employers might still pay their existing workers more if these participative work systems required higher levels of effort or some distinctive behavior to operate effectively. For example, the reduced monitoring by supervisors associated with employee involvement systems might suggest a greater need for employees to self-monitor and ensure that their work performance is up to standards. One might think of such payments as something like an efficiency wage premium paid to ensure better performance in situations requiring greater employee discretion.

These high performance work practices are aimed largely at production or front-line jobs. How they might affect the compensation of other employees, especially supervisors and managers, is even less obvious. Adler (1993) observes, for example, that many of the tasks in factories previously performed by industrial engineers, such as job analysis and redesign, are now being pushed down to the production teams. It might seem reasonable, therefore, to assume that these changes in work organization would reduce the requirements of supervisory jobs and lower their wage. On the other hand, the tasks transferred to front-line workers may be among the simpler ones performed by supervisors and managers. What remains for the supervisory jobs, in turn, may be on average more complicated tasks. 8 In addition, "supervising" a self-managed team may require very different and more complex skills than the traditional supervisor model of simply directing tasks, leading to higher compensation. These complications suggest the importance of examining the effects of high performance work practices on jobs at different levels in the organization.

Research examining the effects of these work systems on employee outcomes in general and wages in 8 An analogy might be how Automated Teller Machines [ATM's] have taken over the simpler tasks of tellers, 
particular has only begun, and the results suggest no clear pattern. Handel and Gittleman (1999) use the Bureau of Labor Statistic's Employer-Provided Training survey and find no relationship between innovative work practices and higher wages. Osterman (2000), using his National Establishment Survey, finds that establishments switching to high performance work systems do not show greater wage increases than those not adopting such systems. Appelbaum, Bailey, and Berg (2000) survey workers in 40 firms across three industries and find higher wages, controlling for worker characteristics, where employee participation, communication, and autonomy are greater.

The theoretical challenges facing estimates of relationships between work systems and wages are similar to those facing estimates of computer use and wages. Because we do not know with certainty exactly how these work systems change job requirements, it is difficult to be certain what theoretical frameworks and hypotheses should drive the analyses.

The empirical challenges facing estimates of relationships between wages and both computer use and work systems are also similar and suggest two requirements for new research:

- $\quad$ The estimates based on individual-level data (i.e., most of the computer studies) cannot adequately tell whether employers with these arrangement are systematically different in ways that may affect wages, such as having more capital per worker or being in industries with different production functions and job requirements. Estimates based on employer data (i.e., most of the work organization studies) cannot tell whether the employees are different in ways that are affecting wages. The best analyses, therefore, should contain information on both employer and employee characteristics.

- $\quad$ Recent research noted above demonstrating that computer-based technology and innovative work systems covary suggests the need to examine both arrangements simultaneously in order to avoid incorrectly attributing the effects of one arrangement to the other.

\section{RESEARCH MODELS.}

Below we examine the relationships between workplace innovations in the form of computer use and new work systems and the pay of employees by occupation. Given the discussion above about the limited guidance from theory in this context, the question is how to best model that relationship. One approach might be to model explicitly each of the major theoretical arguments outlined above with a system of equations where the first equation examines the relationship between these innovations and the relevant aspect of the jobs that has changed. A second equation would then examine the relationship between the respective change in the jobs and their pay. For example, to test the human capital model, computer use and work innovations would

leaving tellers with only the more complicated transactions and raising their job requirements. 
be used to estimate the extent to which skill requirements have changed, and that estimate, in turn, used to predict pay; to test compensating differential theory, these innovations would be used to generate estimates of the utility of jobs (such as job satisfaction), with the utility estimates then used to predict pay; to test efficiency wage theory, the innovations would be added to structural equations modeling the costs of supervision and modeling, on the one hand, and the benefits (costs) of employee effort (shirking), on the other, and the resulting net benefit impact estimates could then be regressed against pay.

In addition to being lengthy and complicated to present and interpret, the difficulty with this approach is that it requires appropriate instruments for each relevant change in jobs - skill requirements, utility, shirking and monitoring costs - to be used as dependent variables in the first equation and then regressors for each of the two models that are independent of each other. At present, we know of no data sets that could accomplish these tasks.

A much simpler alternative that avoids these severe data requirements is to estimate the reduced form of these models by simply examining the relationship between computer use and new work organization practices and pay directly in a single equation. Because the reduced form is similar for all of the theories outlined above, it makes the estimation much more compact, especially in terms of data requirements. It does, however, make it more difficult a priori to distinguish between the different theoretical frameworks, although the results themselves may shed light on which theories are appropriate.

\section{DATA AND ANALYSES}

The EQW National Employer Survey: In order to address these questions, we need data about work practices, technology, and wages, a combination that has been difficult to find in the same data set. An establishment-level survey of employment practices conducted by the Bureau of the Census for the National Center on the Educational Quality of the Workforce (EQW) contains such data and allows us to address some of the above questions.

The EQW National Employers Survey was administered by the U.S. Bureau of the Census as a telephone survey in August and September 1994 to a nationally representative sample of private establishments with more than 20 employees. The survey represents a unique source of information on how employers recruit workers, organize work, invest in physical capital, and utilize education and training investments. It is structured to provide information on all categories of incumbent workers, not just new hires or those in core occupations.

The survey oversampled establishments in the manufacturing sector and establishments with over 100 employees. Public sector employers, not-for-profit institutions, and corporate headquarters were excluded from the sample. Although the survey excluded establishments with less than 20 employees (which represent 
approximately 85 percent of all establishments in the U.S.) the sampling frame represents establishments that employ approximately 75 percent of all workers. This is because while most establishments are small (fewer than 5 employees), most workers are employed in larger establishments. 9 The target respondent in the manufacturing sector was the plant manager and in the non-manufacturing sector was the local business site manager. The survey was designed to allow for multiple respondents so that information could be obtained from establishments that kept financial information, for example, in a separate office -- typically at corporate headquarters for multi-establishment enterprises. Computer Assisted Telephone Interviewing (CATI) was used to administer each survey.

The sampling frame for the survey was the Bureau of the Census SSEL file, one of the most comprehensive and up-to-date listings of establishments in the United States. Of the 4,633 eligible establishments who were contacted by Census, 1,275 refused to participate in the survey. This represents a 72 percent response rate, which is substantially higher than similar establishment surveys in the U.S. The most common reason given by employers about why they would not participate in the survey was that they did not participate in voluntary surveys or were too busy to participate. Probit analysis conducted by Lynch and Black (1995) of the characteristics of nonrespondents indicates that there was no significant pattern at the two-digit industry level in the likelihood of participating in the survey. The only differentiating characteristic of establishments less likely to participate was that manufacturing establishments with more than 1000 employees, 0.1 percent of the sample, were less likely to do so. Of the 3,358 establishments who participated in the survey, not all respondents completed all parts of the survey by the interview cutoff date of October 1 , 1994. The final number of surveys in which all sections of the survey (but not necessarily all items in the survey) were completed was 1,621 establishments in the manufacturing sector and 1,324 establishments in the non-manufacturing sector. This represents a 64 percent overall 'completed' survey response rate. For the analyses below, we restricted the sample to establishments reporting useable data for all questions used in any of the regressions to ensure that differences across specifications or across different dependent variables do not reflect changes in the sample, accounting for a sharp decline in the usable sample size. ${ }^{10}$

The survey was repeated again in August of 1997 (NES II) and administered by the U.S. Bureau of

\footnotetext{
9. Because there are few surveys of employer practices and fewer still that include small establishments, we do not know whether their practices differ systematically from those of larger establishments. The general finding that wages are higher in larger establishments may imply the wages are lower in those establishments that are excluded from this survey, although we do not know whether that overall relationship is linear below workforces of 20 employees. Whether selection bias affects these analyses depends not on whether wages are systematically lower for the omitted establishments but whether the relationship between computer use, work practices, and wages is different for these smaller establishments. It is difficult to speculate as to whether that is the case. Restricting the range of the dependent variable by eliminating respondents whose wages are lower should, other things equal, make it more difficult to find statistically significant relationships with the independent variables.

10 Spot checks of individual regressions failed to reveal evidence that restricting the sample to establishments reporting all variables, not simply those used in the regression in question, affected the results.
} 
the Census via Computer Assisted Telephone Interviewing (CATI). The sampling frame was again drawn from the (SSEL), targeting business establishments throughout the United States and excluding those with fewer than 20 employees. Once again the survey over-sampled the nation's largest establishments and those in the manufacturing sector. The sample for the NES II has three components including; an over sampling of states involved in particular educational reform efforts (2,000 completed interviews in California, Kentucky, Michigan, Maryland, and Pennsylvania); approximately 2,500 completed interviews that comprise a representative sample of the rest of the United States (45 states plus the District of Columbia); and a longitudinal component of about 900 completed interviews with business establishments that had participated in the initial National Employer Survey, the component of interest for this paper. A total of 5,465 establishments responded to NES II for a response rate of 78 percent. Nine hundred and fifteen responded to the longitudinal component for a response rate of 88 percent. Excluding partial responses brought the sample down to 766 and a completed response rate of 74 percent.

The NES asked for the "average pay for the following categories of full-time employees" in each establishment: (1) managers and professionals, (2) supervisors, (3) technical or technical support workers, (4) office, clerical, and administrative support workers, and (5) production or front-line, sales or customer-service workers. This classification system allows us to report estimates of relationships separately by occupation. Each pay amount was accompanied by a second response indicating the appropriate periodicity: hourly, weekly, monthly, or annual. Sixty percent of the responses across occupation reported pay in annual terms, and 33 percent reported it hourly. A separate question asked for the average hours per week by occupational categories. In the 1994 survey, hours were elicited only for the last three categories, above. We imputed 1994 manager and supervisor hours using the coefficients of regressions of 1997 hours on the maximum of the three hours variables also available in 1994 (analyses available on request). The dependent variable measures annual pay, which was calculated for those respondents who reported pay over shorter periods based on reported hours per week and assuming an average of 51 weeks/ 12 months per year. We include reporting-type dummies in all the analyses to control for any error in these assumptions.

The variables measure pay (not compensation, which includes benefits) and come from the respondent rather than directly from establishment records. While we cannot know exactly how the respondents generated their answers, it is quite likely that some were reporting an estimate rather than an average calculated from their full-time employee's pay. If round numbers are a necessary condition for estimates, then the hourly pay reporters did not appear on average to be giving estimates as only 15 percent of those responses were divisible by 10 . The annual reporters may have been much more likely to have done so as about 60 percent gave responses divisible by 2,000. Given this pattern, the reporting period control variables noted above should help capture differences in rounding estimates. Respondents who were not calculating actual average wages may 
well have been reporting the pay for a typical or modal worker: Plant and office managers should be expected to know such information. For those reporting annual wages, we cannot be sure whether they were using the most recent fiscal year, which would have just ended, or the previous calendar year. No doubt these data contain a great deal of measurement error, although it is difficult to estimate the error, given the absence of other data to validate these responses, and there is no reason to think that the responses are necessarily biased.

It is possible that overtime pay for non-exempt workers might be driving some of the variance in annual pay. While this is not necessarily a problem for the analysis, it would be important to know whether workers who use computers or high performance work practices are earning more because they have more overtime pay. We perform a series of analyses to examine the overtime question, which are described in the Appendix. We find that employees in establishments with teamwork and profit sharing/stock options work significantly longer hours. We include controls for hours in the analyses that follow, and they do not change the results in any fundamental way.

All of the variables used in our analyses are described in Table 1, which presents the definitions, and Table 2, which gives their means and standard deviations. The independent variables begin with two variables measuring the percentage of supervisors and managers using computers and the percentage of production workers and other non-exempt employees using computers on their jobs. We have several variables measuring new work systems including whether the establishment has a Total Quality Management (TQM) program.11 These programs typically involve important changes in work organization, transferring quality control monitoring and problem-solving tasks to front-line workers. The percentage of the workforce involved in selfmanaged teams captures a work system where teams take over virtually all of the traditional supervisory responsibilities. The percentage of employees in regularly scheduled meetings to discuss work-related issues is a proxy for more general employee involvement. Job rotation is a practice thought to broaden jobs. We also include two other variables that proxy the extent of employee involvement in decision making: The number of levels or layers in the organization (with fewer levels seen as "flatter," less formal organizations with fewer rules and procedures and more authority for decisions left to employees) and the ratio of employees to supervisors, or the "span of control" (with a lower ratio associated with less close supervision and more scope for employee decision making). We also look at profit sharing/stock options as one of the more important practices designed to support employee involvement by helping to create financial incentives for employees to act in the interests of the organization. Finally, we include organizational benchmarking in part as a control for establishments that are more likely to pursue best practices in all areas of operations (practices that may both

11 The TQM question was only asked in the 1994 NES survey. To retain this important variable we code 1997 observations using their 1994 response if it is available; otherwise we set this variable to zero and code a missing data dummy variable (see Table 1). 
raise wages and covary with computer use and work organization innovations). Benchmarking may also raise job demands to the extent that employees are involved in comparing their own practices, learning about new ones, and adopting innovations. Different variables have been used in the conceptualization of high performance work by other authors, and there has not been much consistency in the choices (see, e.g., Becker and Gerhardt 1996). We believe, however, that the core issue in these innovative work systems and across the studies is employee involvement and that we have captured that aspect with our measures.

\section{[Tables 1 and 2]}

In general, we expect both computer use and high performance work practices to be associated with higher wages, other things equal, and for these relationships to be similar across occupations. But there are some relationships that might be expected to differ by occupation. For example, because TQM and selfmanaged teams are practices associated mainly with production and front-line work, we do not expect strong relationships between these variables and the wages of other occupations that make less use of such practices, such as clerical employees and technicians. We include the analyses for these occupations for comparison purposes. With respect to supervisors and managers, we might expect computer use by their subordinates to raise their own job demands and wages on the assumption that it adds complexity to the jobs they supervise. Whether team work and TQM reduces their job demands, in turn reducing wages, by transferring tasks to front-line workers or whether these practices demand different and possibly more complicated approaches to supervision and management that might lead to higher wages is an empirical question.

\section{Human Capital Issues}

As suggested earlier, the most promising explanation as to why wages might be higher in the presence of computer use and innovative work systems is human capital, that job requirements demand more of scarce skills. To the extent this is the case, we should expect to see establishments that make greater use of these practices also having workers with more human capital: Higher wages would result not necessarily from the direct effect of computer use and work practices on a given set of workers but from the indirect effect of requiring a more skilled workforce.

The NES asks a series of questions about how the employer selects employees -- what type of information about applicants do they use (such as ability tests) and how important is it in their decision. We use a condensed set of indices generated from the principle component of these questions as control variables. We assume that establishments that want to have employees with more human capital in the equivalent job would use more information about applicants in selection.12 In addition, we include the

12 There may be some endogeneity in that higher wages may lead to a more qualified applicant pool. The hiring questions might not be completely accurate controls for the skills needed in a workforce if it was easier to recruit at higher wages than at lower ones. Higher wages also lead to a larger pool of applicants, however, which could 
average education level for the respective occupational group in the establishment as a human capital control. If computers and these work organization practices are raising skill requirements in ways that make greater demands on human capital as traditionally defined, we would expect education levels in the workforce to be higher. We also control for the potential complementarity or substitution of educational human capital between broadly defined categories of workers as might happen if work spilled over from one occupational group to another by including in each occupation's equation the average education of the closely-related occupational group or groups: the average of managers, professionals and supervisors in the front-line, clerical, and technical workers' wage equations; production and technical workers in the managers (plus professionals) and supervisors' wage equations.

To augment the information about the human capital of the employees in each establishment, we match the NES with data on individual employees--from the 1990 Decennial Census-in the New WorkerEstablishment Characteristics Database. This data set uses address information in the Standard Statistical Establishment List (SSEL) and 1990 Census Long-form place-of-work address information, along with other information, to match employees to establishments. ${ }^{13}$ For those NES establishments matched to a sufficient number of workers in production occupations, we calculate average worker characteristics for these workers and add these to our base production worker wage specifications as further controls. The variables added are average Mincerian experience (age minus years of education minus five) including its squared term, gender of the respondents, and their marital status. The match yielded few nonmanufacturing settings and non-production occupations (attempts to estimate equations for non-production workers yielded small samples and a pattern of results similar to those without the matching - typically insignificant relationships). We were left with a sample of just under 600 NES manufacturing establishments with matching worker data.14

In competitive labor markets, firms should be price takers, and the characteristics that define firms and that are relevant to include as control variables are those that might otherwise affect skill requirements or that

increase the need for screening because of greater variance in the pool even if their average quality rose. The starting wage, ceterius paribus, will attract all applicants whose reservation prices is less than or equal to that wage.

Assuming that reservation prices proxy skills and other attributes, raising the starting wage will not only lead to more applicants but to a pool with greater variance in attributes, requiring more screening to sort out the good ones.

13. For a detailed description of these data and methods, see Kim Bayard, Judith Hellerstein, David Neumark, and Kenneth Troske, "New Worker-Establishment Data Base," Center for Economic Studies of the U.S. Bureau of the Census, Working Paper 2000. For an overview and application, see the same authors' "New Evidence on Sex Segregation and Sex Differences in Wages from Matched Employer-Employee Data," N.B.E.R. Working Paper \#7003, March 1999.

14 This match rate is surprisingly good, given that the NWECD obtained matching worker data for only $7 \%$ of manufacturing establishments (15\% of workers of with manufacturing industry codes), and is probably due largely to NES over-sampling of large establishments. The sample is unlikely to be representative of U.S. manufacturing, however. Many of the establishments still remaining in our data set have only small numbers of production workers. We repeated the analyses shown in Table 4 using only establishments with 5 or more workers - this eliminates about 
might be correlated with the independent variables of interest. These include industry category at the two-digit level, establishment size, whether the establishment is part of a multi-establishment operation, the capital stock to labor measure, the percentage of the workforce covered by collective bargaining agreements, a proxy for turnover, and the percentage of the workforce accounted for by production and supervisory employees (establishments with a higher proportion of "other" workers - mainly managers and supervisors - may be doing different kinds of work).

A potential issue with the reduced form approach noted above is that wage levels may affect the choice of practices. This is perhaps most obvious with capital decisions like computer purchases where capital could be substituted for labor depending on relative prices. But it may also operate for the work practices: Increasing the employee to supervisor ratio might be more attractive where supervisory workers are more expensive, for example. Where wages affect the choice of practices, the relationship may well be recursive, as Bartel and Lichtenberg (1987) argue in a similar context -- practices drive wages, which then affect the choice of practices, etc. In that case, more straightforward, single equation OLS techniques may be sufficient.

To explore how sensitive our results are to treating the practices as exogenous, we conducted several Hausman tests. Most of these used an omitted-variable form of the test suggested by Kennedy (1993, p. 148), which tests for correlation between candidate instruments for the potentially endogenous practice variables and the OLS error term - a necessary condition for rejecting exogeneity in the original form of the Hausman test-by simply adding them to the original OLS model and testing their joint significance. 15 Two advantages of this form, for our purposes, are that it is extremely simple to conduct and makes it possible to test all the combinations of practices that can be identified by the instruments.

As with all such tests, the results depend crucially on the validity of the instrumental variables, which should be relevant theoretically to the analysis, not already in the analysis, and also exogenous with respect to the dependent variable. As is often the case, it is difficult to find plausible candidates for instruments. The most obvious candidates were already included in our original research design or the variables proved to have essentially no correlation with the practices after partialing out the effect of control variables.

We conducted our simple variant on the Hausman test using the potential instruments for the highperformance practices we were able to identify, classifying them into two groups: (1) two variables giving the expenditure on recruiting and formal training, respectively, as a percentage of labor costs, which might reflect higher skill requirements (2) a set of -MSA-level geographic area characteristics from the 1990 decennial

65 observations - and the results were essentially unchanged.

15. See Kennedy (1993), p. 148. It appears Kennedy or earlier applied researchers may have mistaken the test he proposes for a regression-form test proposed by Hausman that is exactly equivalent to the original equivalent forms as developed by Durbin, Wu, and Hausman (see Judge, et al, 1981). . However, we follow Kennedy in referring to his test as an "omitted variable form Hausman test." 
Census, including educational levels in the area workforces, income per capita, and male and female employment rates, matched to each establishment, which might reflect higher human capital.16 Recruiting as a percentage of labor costs entered all the models with a negative sign, suggesting that rather than picking up more extensive search and intensive screening of applicants, this variable simply suffers from denominator bias (wages being the most important component of labor costs), and was significant only in the supervisors' equations. Training usually had the expected positive sign, but was not significant—nor did it ever contribute to a significant rejection of exogeneity in the original-form Hausman tests we conducted. The Census geographic characteristics data, on the other hand, did tend to be significant when added to the OLS wage equations, especially the per capita income measure. (Indeed, one could certainly argue that they should be included in as control variables.) However, these variables, alone or in combination with the other instrumental variables, only led to significant original-form Hausman tests in the regressions where the OLS results for the work practices were weakest and, therefore, did not change the qualitative conclusions of our analysis. This juxtaposition of results for the geographic variables is explained by their low correlations with the work practice variables, particularly after the effects of the other control variables are partialed out. The appropriate conclusion, therefore, may be that while our tests do not imply endogeneity in the data, we also seem to lack good instruments for testing it.

Given that we have data from 1994 and 1997, one alternative might be to examine the relationship between changes in the introduction of computer use and work practices in the two periods and changes in wages. This is essentially the technique used by Osterman (2000). But there are several problems with this approach. The first is what is sometimes called the "late adopter" issue, a version of the more general problem that those establishments who adopt new practices are different in important ways that may have direct relationships with wage outcomes. For example, the establishments that wait to adopt high performance work practices years after they have become popular may well be backward in other ways as well that are difficult to

16 The 1997 survey asked for the dollar expenditure on training, so the percentage was constructed by dividing by labor costs; the 1994 survey asked for the percentage directly. The full sample mean of this variable was $9 \%$ $(\mathrm{N}=2606)$ and that for the recruiting percentage was $3.8 \%(\mathrm{~N}=2798)$.

The 1990 Census geographic area statistics variables were weighted averages - using population weights for population statistics, worker population weights for workforce statistics, and so on (but simply summing the total population measure)--of the respective county-level statistics. To maximize the correlations between these instruments and the practices, after partialling out the other variables in the models, we used two different type of geographic averages: for the education-level share and income variables, we used MSA-level averages; but for the other variables we used the establishment's own county plus all counties with Census Summary Tape File 3a internal points (usually close to the centroid) within 35 miles. (As it turns out, the results are very similar if all the variables are constructed in either one of the two ways, both in terms of the Hausman tests and the in terms of the means of the variables across the NES establishments.) The following geographic characteristic variables (means in parentheses) were used ( $\mathrm{N}=4297)$ : \% w/ no highschool diploma (25), \% highschool graduates $(31 \%), \%$-year college graduates (19.5\%) ["some college" and 2-year graduates formed the omitted group]; log of total population (13.9); \% working within a metro area (78), \% living in urban area (73); household income per capita (14,317); percent of civilian labor force aged 20 or more employed (64), and the female labor force participation rate (57). 
control for and that may affect wage outcomes. The second problem is the more general issue of measurement error, which is exacerbated in panel data. Approaches that rely on differences in responses between 1994 and 1997 compound the measurement error associated with the 1994 reports and the 1997 reports (i.e., the errors in both reports are included in measures of the differences between them; see Becker and Huselid (1996), for an example, who argue against this technique). Perhaps many of those reporting changes in practices in fact may simply have not reported accurately in one of the two periods. This is particularly relevant given the short time period between observations during which one might not otherwise expect many changes in practices. When we estimated the cross-sectional models reported below in first-differenced form on the 1994-97 panel, the overall estimation performed very poorly, typically with only one or two of the differenced control variables achieving statistical significance (the capital to labor ratio was the only robust contribution). Among the independent variables, only the variable for profit sharing/stock options showed any evidence of significance, albeit scattered and weak. These results are available on request.

The analyses reported below are for the pooled 1994 and 1997 data. The estimation method treats the establishment identifier as that of non-independent sampling clusters, and the reported standard errors are (Huber/White) robust standard errors, accordingly adjusted.17 Because two of the control variablesthe percentages of workers with less than one year of tenure and in 'front line' (production or supervisory) occupations - were based on questions directed toward all workers in 1994, but only toward "permanent" workers in 1997, we interact these variables with the 1997 year dummy to see whether this reporting difference mattered. It did not. Analyses using the 1994 and 1997 data separately are available on request and generally produced similar results. We performed Wald tests as to the appropriateness of pooling the two samples based on many different specifications for the production occupation wage equations and, in general, it was not rejected. ${ }^{18}$

\section{RESULTS}

17. "Robust,"standard errors do not assume classical relationship between the sample and population parameters; instead of expressing the variance of the estimate around some "true' population parameter, the more conservative, robust standard errors simply estimate the asymptotic variance of the resulting parameter estimates, were the same sampling and estimation procedures to be infinitely repeated.

18. First we tested interactions of the practices with the year dummy, either entered along with such interactions for control variables or alone. Estimated coefficients on these yearXpractice terms were uniformly very small and these tests yielded F-statistics extremely close to zero. Next we tested the joint significance of year interactions with both the practices and all the (not already interacted) controls except for the industry and size dummies. Pooling was also not rejected here for the separate models for manufacturing and non-manufacturing (although the p-value for the manufacturing model with all the practices and the human capital controls did fall between .05 and .10). Pooling was rejected (p-value of .03), however, for the most inclusive model for all industries combined. In the various tests, a tendency toward significant interactions with the 1997 year dummy was most noticeable for the percent unionized variable (a negative interaction, indicating a declining union premium), production workers' average education (positive), and for one or two of the variables pertaining to the age distribution of the capital stock. 
Table 3 presents the results by occupation, with and without controls for human capital. Results are reported separately for manufacturing and non-manufacturing because the high performance work practice variables in particular may have different meanings in manufacturing, where they originated and have typically been studied, than in non-manufacturing. We also estimated the pay regressions for all industries combined with a full set of industry dummies but the other coefficients constrained to be equal across manufacturing and non-manufacturing. Because of potential collinearity among the work organization practices, we add them to the model in two stages. The first set of estimates focuses on just the four primary high performance work practices--teams, employee involvement in decision-making, job rotation and TQM. These four practices are actually the most closely intertwined empirically, tending to group together in principle components analyses of all the work practice-related survey items (see below). A second set of columns shows the results of adding variables for benchmarking, profit sharing/stock options, the supervisory ratio, and the number of organizational levels. We also report in Appendix 1 the complete results for all control variables for the most important wage regressions noted below.

\section{Results for Production/Front-Line Workers.}

We begin with production and front-line workers, the occupational category where high performance work practices are targeted, and with the manufacturing sector, where they originated. Computer use is uniformly associated with significantly higher wages. All the primary high performance practices - teams, employee involvement and TQM-also show significant relationships with wages. The relationship with wages is significant but negative for job rotation. The other unexpected result is that greater computer use among managers and supervisors is associated with higher wages for production and front-line workers. This relationship might be a proxy for some other, unobserved characteristic of the organization: An establishment whose executives make greater use of computers, for example, might be one that is more sophisticated in other ways. Including the various controls for human capital from the NES leads to a substantial drop in the size of the coefficients - from about half to a third reduction - but all the coefficients remain significant except that on teams in the all industries/all practices model. These results support the notion that an important component of the higher wages associated with computer use and high performance work systems is attributable to higher human capital.

While the results for computer usage are similar in the non-manufacturing estimates, none of the four primary work practices show statistically significant relationships with front-line worker wages outside of manufacturing. The lower sample size available for non-manufacturing appears only partly responsible for this. While all four coefficients are less precisely estimated than for manufacturing production workers, the negative coefficients on job rotation and the positive estimates for TQM are only about sixty percent as large as in the 
corresponding manufacturing estimates. The point estimates for the two sectors differ even further for the percentage meeting regularly and for teams — with the latter actually falling below zero for non-manufacturing when human capital controls are added. It may be that these high performance work practices have not translated to increased productivity outside of manufacturing, where they originated or, as Osterman (2000) has argued, that they have but workers have not shared in any gains. ${ }^{19}$

Three of the four secondary practices are related to production or front-line wages in the expected direction, both in and outside of manufacturing. Benchmarking is associated with about 3 percent higher wages, though the coefficients are not significant in the non-manufacturing equations. In all the estimates, payment of profit sharing bonuses or receipt of stock options is associated with significantly higher pay. Given that profit sharing and stock options are not included in the respondent's definition of hourly wages, this result suggests that wages are higher when establishments have profit sharing and stock options independent of the additional value of those benefits. ${ }^{20}$ Decreases in the number of levels in the management hierarchy also show positive and significant relationships with wages. In both sectors, attenuated supervision, in the form of more workers per supervisor, yields lower wages, which would seem to imply that the greater autonomy necessary where supervision is lower is not rewarded. An alternative view might be that what supervisors do is not necessarily monitor workers but offer additional resources. According to responses to the 1994 NES survey, for example, about 20 percent of supervisors' time is devoted to providing informal training. The fact that the coefficients fall to near zero when human capital controls are added further suggests that supervisory ratios may be complements to the human capital of their supervisees.

\section{Adding 1990 Census Individual Controls.}

We also estimate the above relationships for production workers in a manufacturing context adding the additional information on employee characteristics from 1990 that were described above. Only the percentage of workers meeting regularly in teams and computer use remain significant when these variables are added. When compared to the findings above, these results suggest that worker characteristics and human capital differences broadly defined seem to account for much of the significant relationships between work practices and higher wages. Together, these arguments are consistent with the view that high performance work

19 Another possibility is that these practices have been selectively applied to lower-skilled (higher-skilled) workers in non-manufacturing (manufacturing) in ways that we cannot observe, and we have mistaken differences in selection bias across the sectors for differences in treatment effects.

20 We test to see whether respondents, especially those reporting annual wages, may have factored the value of profit sharing and stock options into their responses by interacting those who report wages annually with the profit sharing variable. The results are insignificant and close to zero except for managers and supervisors where the result was significant at the five-percent level and negative. It is unlikely, therefore, that annual reporters with profit sharing were including any profits in their wage estimates because, other things equal, those estimates were either no 
practices demand more from employees, raising the average human capital characteristics of the employees and their wages as a result. On the other hand, teamwork is associated with higher wages even after controlling for a wide range of human capital and organizational characteristics. Something about teamwork is raising wages even for otherwise equivalent production workers.

\section{Results for Other Occupations.}

The results for other occupations show reasonably consistent positive and significant relationships with computer use. The fact that computer use among managers and supervisors also raises the wages for technicians and office workers in manufacturing repeats the somewhat surprising findings for production and for front-line workers. Conversely, for managers and supervisors, while their own computer usage is generally associated with somewhat higher pay, computer use by non-supervisory workers has larger and robustly significant positive effects on their pay in both manufacturing and non-manufacturing. The comparison between these two variables should be taken as merely suggestive, however, as the two computer usage variables are fairly highly correlated--.38 in manufacturing and .49 in non-manufacturing, and exploratory testing of such differences rarely found them to be significant. The negative and significant relationship with job rotation also shows up for all the other occupations as well. The other relationships with the primary set of work practices are virtually all positive, including the effects of high performance work practices on supervisors' pay, but they tend not to be significant, especially in the presence of the NES worker characteristics controls.

Among the secondary set of practices, profit sharing/stock options is positive, significantly so for across occupations in the All Industries results, as is benchmarking. A flattened management hierarchy is associated with higher pay for managers in non-manufacturing but not in manufacturing. Supervisor pay, on the other hand, is significantly related to the number of management levels in the expected direction in both sectors. Technical and office worker pay appears unaffected by these variables.

One potential explanation for the lack of stronger relationships between work practices and wages is collinearity among the practices. This is an especially important argument given the belief that high performance practices tend to operate as systems. One way to consider this potential explanation is to create an index that combines the high performance practices into a single scale. To implement such an approach, we first standardized the four primary practices by subtracting the mean and dividing by the standard deviation, separately for manufacturing and non-manufacturing. We then repeated the regressions in Table 3, variously substituting sums of these z-scores for the individual practice variables. In particular, we tried several different versions of these summary scores: the sum of all four (retaining the control for missing TQM in 1997 in one set

different or lower. These results are available on request. 
and restricting the sample to the 1994 survey in another), the sum of the three z-scores for the percentages involved in teams, meetings and job rotation, and, finally, in recognition of having found negative effects for job rotation, just the sum for teams and meeting. In each of the latter cases we estimated the models both with and without including the primary practices excluded from the sum. Despite the large number of regressions this represents, the results of this exploratory exercise can be summarized fairly succinctly: when even one of the individual practices' coefficients are significant, and where the significant coefficients are unidirectional, the combined index is significant; in other situations, it is insignificant. The one exception to this is that for production workers in manufacturing, combining all four primary practices yields a significant, positive coefficient even though job rotation has a significant, negative coefficient when entered separately. (This particular combination represents a common model for high performance work systems: The full results are available on request.) These results support the notion that high performance practices are related to higher wages, at least for some occupations, and they do not suggest that colinearity between individual practices is obscuring the estimated relationships.

\section{Possible Synergies Between Practices:}

Arguments about synergies among practices, that combinations of practices create greater performance outcomes than each would generate individually, have been central to notions about high performance work in particular. These arguments do not neatly transfer to employee outcomes, however. It is not clear, for example, that combinations of the practices create additional skill or job demands that require compensation, although if they do generate synergies in performance outcomes, they may make the jobs with such characteristics more important.

We nevertheless examined the possibility that synergies between practices might also generate higher wages. We repeat the above equations adding a series of two-way interactions between the relevant work practices, TQM, teamwork, self-managed teams, and job rotation. The results, available on request, find essentially no significant interactions for any combinations across the various occupations. This test does not completely rule out the possibility of synergies -it is always possible to look at three-way and other interactions and specific contexts - but it does not offer encouragement that such synergies exist.

\section{Conclusions}

These results shed light on some of the factors that are changing the wage structure in the economy. The analyses of computer use extend an established body of research, generally supporting prior conclusions, and reveals some of the complexities about its relationship with wages. The fact that the wage premiums associated with use of computers are not as great as in some prior studies based on individual-level data may be 
in part because this study contains establishment-level control variables including work practices that have been found to covary with computer use and, as found above, are associated with higher wages. The fact that the relationships exist even in the presence of reasonably elaborate controls for organizational characteristics suggests that the higher wages are not simply an artifact of unobserved firm characteristics. The fact that the relationship exists for production workers in manufacturing after adding additional controls for individual characteristics suggests that computers may change jobs in ways that demand more than just additional human capital of the kind that we can measure.

The results for work organization variables and the secondary practices that support them suggest that, on average, employees do seem to benefit from them in the form of higher wages. But this relationship is largely limited to the manufacturing context. It could be that these practices simply do not mean the same thing in a non-manufacturing context; or if they do, then employees do not benefit from them. Interestingly, the supporting practices seem to have stronger relationships with higher wages across more occupations than do the "core" practices. The explanation would seem to be that these other practices are more easily applicable outside of manufacturing and production work than are the core practices.

The most puzzling result may be the significant negative relationship between job rotation and wages, a relationship that holds up across virtually all of the specifications. The result is puzzling because job rotation is seen as a central component of most high performance work systems, especially Japanese influenced systems such as lean production. One possible explanation for this result might be that job rotation does generate higher wages but only works in the context of other practices such as teamwork, which it is designed to support, and therefore vanishes when one controls for these other practices: When we combine job rotation into a principle component with teamwork and other practices, the overall result remains positive for production workers in manufacturing. This might explain why the relationship is not significantly positive, but it does not explain why the marginal effects of job rotation tend to be negative and significant. Another explanation might be that, other things equal, job rotation proxies situations where jobs are simpler, which is why employees can rotate across them: Situations where there is job rotation and other practices such as teamwork may identify the more challenging positions while those where there is job rotation but no teamwork or other practices identify situations where the jobs are so simple that it does not matter who does them. In that sense, job rotation per se may be a proxy for lower-skill requirements.

Analyses with and without the various human capital controls indicates that an important component of the overall wage premium at the establishments that make greater use of computers and of high performance work practices can be attributed to higher human capital. As the earlier discussion noted, it is difficult a priori to know what affect these work practices and computer use have on work and therefore to know what theoretical framework is appropriate for examining them. The pattern of results 
noted above suggests that the human capital model seems most applicable. Yet there also appears to be some premium for computer use and teamwork that cannot be accounted for by traditional human capital measures, including our merged individual-level data. No doubt there are many other, unobserved aspects of human capital that may be contributing to these wage relationships. On the other hand, unless these unobserved aspects can be identified relatively easily through the selection process, it is difficult to imagine them being the cause of higher market wages (if competitors cannot observe them, they will not bid up wages to hire these workers away). If premiums do exist that cannot be explained by human capital, then it may suggest that computer use and these work practices may demand also effort, diligence, or some other factor consistent with compensating differentials or efficiency wage models.

Overall, computer use and technology both appear to have important effects on wages, especially for front-line, production workers who are the targets of such work systems. The fact that these results do not translate to non-manufacturing suggests, however, that these practices cannot simply be applied in any setting but are in fact sensitive to context. This seems particularly the case for job rotation, which appears actually to lower wages unless in the presence of other innovative work practices. And while it may be possible to get additional benefits from additional practices, we find no evidence of extra benefits from using combinations of practices.

As with most innovations, it is difficult to know the precise general equilibrium effects of computer use or the above work organization practices if they were to be extended to the economy as a whole.21 It is also difficult to know exactly what the overall effects of these innovations are on the establishments. Attempts to examine the relationships between related concepts and establishment performance using these data suggest a mixed picture, but that productivity gains, if any, are small (Cappelli and Neumark 1999; Lynch and Black 2000). It may only take small productivity improvements to fund the kind of wage premiums discovered here, but the jury is still out as to whether those premiums are funded from productivity gains or some other way, such as from profits. The notion that innovative work practices like teamwork in particular might be useful for employers and for employees is an attractive proposition, however, and one that will continue to generate interest.

21 The fact that establishments that use these practices pay their workers more does not necessarily suggest that all workers would find their wages rising by equivalent amounts if all establishments adopted these practices. If the wage premiums come from scarce human capital, then constraints on human capital limit the extent to which wages can increase through the use of these practices. 


\section{Appendix: Estimating the Influence of Overtime Premiums}

Because the pay questions were asked with respect to full-time workers, we assume that any overtime premium - due to either regulation or to a positive correlation between hours and unobserved influences on the wage--is associated with working more than 40 hours per week.22 If reported earnings, Y, for non-hourly reports is based on actual payroll expenditures, it will be related to reported average usual hours per week, $\mathrm{H}$, and the underlying straight-time wage, w, by:

$$
\mathrm{Y}=\operatorname{wMIN}(\mathrm{H}, 40)+(1+\alpha) w M A X(0,40-\mathrm{H}),
$$

where $\alpha$ combines the total of implicit and mandated overtime premia with the fraction of workers covered (e.g., if $100 \%$ of workers receive the FSLA mandated 'time and a half' for overtime but there are no other factors influencing the relation between wages and hours, then $\alpha$ will equal .50). Dividing both sides by $\mathrm{H}$ - as we do with the earnings report to get our wage measure-rearranging and taking logs yields:

$$
\ln (\mathrm{Y} / \mathrm{H})=\ln (\mathrm{w})+\ln \{1+\alpha[\operatorname{MAX}(0, \mathrm{H}-40) / \mathrm{H}]\} \approx \ln (\mathrm{w})+\alpha[\operatorname{MAX}(0, \mathrm{H}-40) / \mathrm{H}] .
$$

Thus, we add $\operatorname{MAX}(0, \mathrm{H}-40) / \mathrm{H}$ (fully interacted with dummies for the four possible pay-reporting periods) as a regressor, allowing the data to determine $\alpha$.

Estimates of $\alpha$ should fall between zero and one. The estimates for hourly (straight-time wage) reporters should be below those who reported weekly, monthly or annual earnings because the latter may have incorporate some mandated overtime premium pay into their reports. An alternative hypothesis, however, is that the non-hourly, earnings reports are unrelated to reported hours, so that $\alpha$ would be -1 for these respondents. This would be the case if the respondents interpret the reference to "average...full-time employees" in the pay questions as instructing them to respond with what a typical worker would earn if he or she worked a 'standard,' full-time week. Finally, another reason to expect that estimates of $\alpha$ for non-hourly reporters might be less than zero is denominator bias: dividing by the reported hours in the survey data to get the wage will impart a negative bias to these variables' coefficients if there is any measurement error in the reported hours.

The estimates of $\alpha$ for non-hourly reporters are, in fact, below zero, and we take this as indicating that most of these reports are computationally (but not necessarily economically) independent of reported hours-

22 . Before imposing a minimum of 40 hours in the denominator for calculating the wage from the raw pay reports we tested this assumption by comparing average wages for establishment-occupation cells reporting 40 to 42 hours with those reporting 35 hours or less, controlling for industry, establishment size and education. In each occupation, the low-hours group's average was significantly higher than the 'standard' hours group's if actual hours were used to calculate wages, but the two differed only trivially if a 40-hour 'floor' was imposed in calculating the wage. We also re-estimated all the wage models adding a log hours variable interacted with reporting type, thereby controlling for hours variation below 40 hours. Using these estimates would not change our conclusions - only very small changes occurred in the coefficients on the work practice and work organization variables - but some of the coefficients for the added hours variables were unreasonably large in absolute value (particularly where the number of identifying observations was quite small). Given that, and the "full-time" wording in the pay questions, we strongly prefer the 
i.e., that they pertain to an idealized, 'standard hours' full-time schedule of 40 hours per week.

The estimates of $\alpha$ for the small fractions of observations that are weekly or monthly pay reports (5 to 9 percent of cases combined) are generally not significantly different from negative one. The estimated $\alpha$ 's for the hourly reporters are, as expected, both significantly greater than zero and significantly less than the FLSA-mandated .50, suggesting they are picking up mostly implicit, as opposed to mandated, overtime premia. The $\alpha$ estimates for the annual reporters (60 to 70 percent of cases), on the other hand, are usually firmly between 0 and -1 (i.e., $95 \%$ confidence intervals exclude both these values). We conclude, therefore, that all three hypothesized influences on reported pay and hours are operating across the various respondents: There are overtime premia, including "implicit" premia because of a relationship between unobserved skill and hours; reporting such that earnings are usually independent of hours; and, where this is not the case, some denominator bias. The overtime hours controls provide the most flexible approach to controlling for the possible relationships between wages and hours, on the one hand, and the work practice and organizational variables and hours, on the other, so we include them in all the analyses. As sensitivity checks, we re-estimated the models (i) without the hours controls, and (ii) using (log) annual earnings calculated independently of reported hours (i.e., using a fixed number of hours per year) as the dependent variable. In both cases, the qualitative conclusions were unchanged: in (ii) the coefficients on the variables of interest all underwent only small changes; in (i) the changes were also generally small, but the coefficient on the job-rotation variable in the managers wage equation for manufacturing dropped from .03 to a significant -.05 as part of a pattern of small but non-negligible negative changes in the job rotation coefficients, most of which were already significant and negative.

specifications without these variables, and omit those with them. 
YEAR 1997: Dummy variable for 1997 survey observations.

PAY, PAY REPORTING AND OVERTIME HOURS

These variables are all available for each of five occupational categories: (1) managers and professionals, (2) supervisors, (3) technical and technical support, (4) office and clerical, and (5) production or front-line. In the Tables reporting regression results, this occupational specificity is suppressed (i.e., the same variable names are repeated, even though there are actually five versions of each variable in the data), as it generally is in the following definitions:

DEPENDENT, WAGE VARIABLES: These are based on questions asking for the "average pay [by occupational category] of full-time employees" in each year. For hourly reporters, WAGE is the reported amount. For weekly, it is the reported amount divided by reported usual weekly hours; unless hours is less than 40, in which case the pay amount is divided by 40 . For monthly and annual reporters annual earnings are divided by annual hours-assuming 51 weeks, 12 months, per year--again basing annual hours on the maximum of reported average usual hours per week and 40 .

WEEKLY, MONTHLY, and ANNUAL: are dummy variables indicating the type of pay reporting (hourly is the leftout category).

OVERTIME_HOURLY, _WEEKLY,_MONTHLY and_ANNUAL: are interactions of the four pay reporting type indicator variables with the overtime share of average usual weekly hours. If hours, $\mathrm{H}$, are greater than 40 , the overtime hours share is $[\mathrm{H}-40] / \mathrm{H}$; otherwise it is zero.

\section{COMPUTERS}

\% MGR/SUPV COMPUTERS: "What percentage of managers and supervisors use computers in their jobs?"

\% NON-SUPV COMPUTERS: "What percentage of your production and non-supervisory employees use computers in their jobs?"

\section{ORGANIZATION}

\% NON-SUPV IN TEAMS: "What percentage of non-managerial and non-supervisory employees are currently involved in self-managed teams?"

\% MEETING REGULARLY: "What percent of non-managerial and non-supervisory employees are involved in regularly scheduled meetings to discuss work-related issues?"

TQM: “Has your establishment adopted a formal Total Quality Management program?" This question was asked in the 1994 survey only.

TQM_MISS: Dummy variable equal to one for 1997 observations not part of the 1994-1997 panel.

\% IN JOB ROTATION: "What percent or how many of non-managerial and non-supervisory employees are currently involved in job rotation?"

BENCHMARKING: "Has your establishment participated in any benchmarking programs that compare your practices and performances with other organizations'?" 
PROFIT SHARING OR STOCK OPT.S: 1997: "Does your establishment contribute toward any of the following employee benefits... stock options or profit sharing" 1994: This variable equals one if respondent answered "yes" by occupation to questions asking if they "provided profit- or gain-sharing or bonuses," or "yes" to "Are your employees covered by any of the following [benefits]...stock options."

MGMT LEVELS: "How many levels are there between a first-line supervisor and the top official in your establishment?" Regressions use the log of this variable plus one.

WKRS-PER-SUPERVISOR: “On average, how many workers report to each front-line supervisor?” [1997 survey adds the interviewer instruction- "IF NO SUPERVISORS, ASK WITH RESPECT TO FRONT-LINE MANAGERS."] Regressions use the logarithm of this variable.

\section{INDUSTRY, SIZE CONTROLS}

Each firm is allocated to one of 20 industries; the industry controls are 20 industry dummy variables. Firms are divided into 5 size categories, where size is determined by the number of employees in the establishment. The size categories are 20-49, 50-99, 100-249, 250-1,000, >1,000.

\section{FIRM CONTROLS}

MULTI-ESTABLISHMENT FIRM INDICATOR": "Is this the only establishment in your enterprise, or are there others?"

LOG OF CAPITAL STOCK/TOTAL EMPLOYMENT RATIO . For manufacturing establishments, this variable is usually obtained by matching to the Census of Manufacturing for the nearest year-1992 for the 1994 NES and 1997 for the 1997 NES - and then deflating to the appropriate year. If, however, the Census of Manufacturing reports zero capital stock, the NES report is used instead. For non-manufacturing establishments, this variable is equal to zero. 23

\% EQUIP. < 1 YR, 1-4 YR, 5-10 YR and >10 YR: "What percent of your machinery or equipment used in production is (a) less than one year old, (b) between one and four years old, (c) between five and ten years old, (d) greater than ten years old?" (Third category is excluded.)

NON-MFG_\% EQUIP $<1$ YR, $\ldots,>10$ YR: The four preceding variables interacted with a dummy variable for non-manufacturing.

\% UNION: "What percentage of your employees are covered by a collective-bargaining agreement?"

\% PRODUCTION/SUPERVISORS: Sum of two responses: "Of your total workforce at this location at the end of 1993 [1996], what percentage were: ... supervisors? [and] production workers? (Sales/customer service/other front-line workers?)"

YEAR 1997_\% PROD/SUPV: Above times YEAR 1997 dummy.

12. NES capital stock reports are missing for many establishments, so to conserve observations we draw this information from the Census of Manufacturing. Outside of manufacturing, the NES capital stock item is either missing or an outlier at especially high rates. Perhaps as a result of these data quality problems, the capital/labor ratio variable tended to be insignificant, or marginally significant at best, in non-manufacturing wage equations (especially when the age of capital stock and industry dummy variables were included), so we dropped the capital variable for non-manufacturing. 
\% FEMALE: "what percent or how many of your employees [1997: "permanent employees"] are women?"

TOTAL WORKFORCE: 1994: The maximum of (i) the response to "How many employees were on your payroll at the end of 1993?" and (ii) the sum of responses to "Of these employees, how many were (a) full-time, (b) parttime, (c) temporary or contract workers?" 1997: The sum of the responses to "How many contract, leased, or temporary workers did you have in 1996" and "tell me the number of employees in each of these three categories. Exclude those agency workers I just asked you about: (a) permanent full-time, (b) permanent parttime, (c) temporary or seasonal workers on your payroll."

\% PART-TIME: One hundred times part-time employment divided by TOTAL EMPLOYMENT.

\% TEMP: One hundred times "temporary or contract" employment [1994], or "contract, leased or temporary" plus “temporary or seasonal” employment [1997], divided by TOTAL EMPLOYMENT.

S' EDUCATION [BY OCCUPATION]: "What is the average number of years of completed schooling for the following categories of employee in your establishment? (a) managers/professionals, (b) supervisors, (c) technical/technical support, (d) office/clerical/sales/customer service, (e) production employees"

The variable MANAGER/SUPERVISOR EDUCATION is the occupation share weighted average of the first two responses; PRODUCTION/TECHNICAL EDUCATION is the weighted average of the third and the last.

TURNOVER PROXY: “What percentage of your currently employed workers [1997: "permanent employees"] have been with you for less than one year?"

YR97_TURNOVER: TURNOVER PROXY multiplied by the 1997 survey dummy.

\section{ADDITIONAL MANUFACTURING PRODUCTION EMPLOYEE ATTRIBUTES FROM 1990 CENSUS DATA.}

Production workers were identified using the 1990 Census occupation codes. The following variables were averaged at the establishment level for these workers:

EXPERIENCE: Age minus education minus five.

EXPERIENCE SQUARED: EXPERIENCE squared (squared before averaging).

MARRIED MEN: Male and ever-married dummy variable.

MARRIED WOMEN: Female and married, spouse present dummy variable.

\section{HIRING CONTROLS}

For the 1994 survey, we utilize several parts of a single, multi-part question: "When you consider hiring a new non-supervisory or production worker (front-line worker), how important are the following in your decision to hire? Please use a scale from 1 to 5 , where 5 is very important and 1 is not important or not considered:...," as follows:

RCRT_EDUCATION: is the sum of responses to three importance-scale items: (i) "years of completed schooling," (ii) "academic performance (grades)," and (iii) "experience or reputation of applicant's school."

RCRT_EXP/CRED: is the sum of responses to "previous work experience of the applicant," and "industry-based 
credentials (certifying applicant's skills).”

RCRT_COMM. SKILL: “Applicant's communication skills.”

RCRT_ATTITUDE: “Applicant's attitude.”

RCRT_TEST SCORE: "Score received in any tests administered as part of the interview."

In the 1997 survey, the same, or very similar, importance-scale items appear after one or the other of two multi-part questions on recruiting to fill a "typical production employee's job title" (supplied by the respondent) job, referred to as "[JOB TITLE]" in the interviewer instructions. The TESTSCORE item is taken from an item- - "Tests administered as part of the interview"- following the first of these questions - "Once you have established a pool of applicants for a(n) [JOB TITLE] opening, what sources of information do you use to evaluate the candidates?...Please use the scale of 1 to 5: (1) Never, (2) Occasionally, (3) Regularly, (4) Often, (5) Always." The other items used to create the above variables for the 1997 survey observations all appear in the next question--"After you have established your applicant pool and obtained information about potential [JOB TITLE] employees, what characteristics or attributes are most critical in making your hiring decision? Please use a scale of 1 to 5: (1) Not at all important, (2) Is of some value, (3) Important, (4) Very important, (5) Essential." (Here, the single, 1994 "previous work experience" response is replaced by four times the response to "previous full-time work experience," plus one times that to "previous after-school or summer work experience," divided by five.) 


\section{BIBLIOGRAPHY}

Adler, Paul. 1986. "Technology and Us." Socialist Review 16 Jan./Feb.

Adler, Paul S. 1993. "Time-and-Motion Regained", Harvard Business Review, Vol.71, No.1 (Jan/Feb), pp.97-108.

Appelbaum, Eileen, Thomas Bailey, and Peter Berg. 2000. Manufacturing Advantage: Why High Performance Work Systems Pay Off. Ithaca, NY: Cornell University Press.

Appelbaum, Eileen and Rosemary Batt. 1994. Transforming Work Systems in the United States. Ithaca, NY: ILR Press.

Ashenfelter, Orley and David Card. 1999. Handbook of Labor Economics. Amsterdam: Elsevier

Attewell, Paul. 1990. "Skill and Occupational Changes in U.S. Manufacturing." Presented at Stanford University Conference on Technology and the Future of Work. 28-29 March. Stanford, California.

Autor, David, Lawrence F. Katz, and Alan B. Krueger. 1998. "Computing Inequality: Have Computers Changed the Labor Market?” The Quarterly Journal of Economics, Vol. 113, No. 4, pp. 1169-1213.

Bartel, Ann P. and Frank R. Lichtenberg. 1987."The Comparative Advantage of Educated Workers in Implementing New Technology." Review of Economics and Statistics. Vol. 69 (February), pp.1-11.

. and Nachum Sicherman. 1995. "Technological Change and the Skill Acquisition of Young Workers." NBER Working Paper No. 5107.

Batt, Rosemary. 1999. "Work Organization, Technology, and Performance in Customer Service and Sales." Industrial and Labor Relations Review, 52(4): 539-561.

Bayard, Kim, Judith Hellerstein, David Neumark, and Kenneth Troske. 2000. "New Worker-Establishment Data Base." Center for Economic Studies of the U.S. Bureau of the Census Working Paper.

. 1999. "New Evidence on Sex Segregation and Sex Differences in Wages from Matched EmployerEmployee Data.” N.B.E.R. Working Paper No. 7003. March.

Becker, Brian and Barry Gerhart. 1996. "The Impact of Human Resource Management on Organizational Performance: Progress and Prospects.” Academy of Management Journal, 39(4), pp. 779-801.

Becker, Brian and Barry Gerhart. 1996. "The Impact of Human Resource Management on Organizational Performance: Progress and Prospects.” Academy of Management Journal, 39(4), pp. 779-801.

Bell, Daniel. 1973. The Coming of Post-Industrial Society. New York: Basic Books.

Berman,, Eli, John Bound, and Zvi Griliches. 1994. "Changes in the Demand for Skilled Labor Within U.S. Manufacturing Industries: Evidence from the Annual Survey of Manufacturing." Quarterly Journal of Economics, Vol. 109, No. 2 (May), pp 367-397.

Berndt, Ernst R. and Catharine J. Morrison. 1991. "High-Tech Capital, Economic Performance, and Labor Composition in U.S. Manufacturing Industries: An Exploratory Analysis." MIT mimeo. 
Black, Sandra E. and Lisa Lynch. 2000. "What's Driving the New Economy: The Benefits of Innovation." Cambridge, MA: NBER Working Paper W7479.

Blauner, Robert. 1964. Alienation and Freedom. Chicago: University of Chicago Press.

Bound, John and George Johnson. 1992. "Changes in the Structure of Wages During the 1980s: An Evaluation of Alternative Explanations." American Economic Review, Vol. 82, No. 3, (June), pp.371-392.

Braverman, Harry. 1974. Labor and Monopoly Capital: The Degradation of Work in the 20th Century. New York: Monthly Review Press.

Bright, James R. 1966. "Increased Automation and Skill Requirements." Technology and the American Economy Washington, D.C.: Government Printing Office.

Bresnahan, Timothy F., Erik Brynjolfsson, and Lorin M. Hitt. 1999, "Information Technology, Workplace Organization and the Demand for Skilled Labor: Firm-level Evidence." Cambridge, MA: NBER Working Paper No. 7136.

Bureau of Labor Statistics. 1988. "Occupational Employment in Manufacturing Industries." Bulletin 2312. Washington, D.C.: Government Printing Office, August.

Cappelli, Peter and David Neumark. 1999. "Do 'High Performance” Work Practices Improve EstablishmentLevel Outcomes?” Cambridge, MA: NBER Working Paper.

and Peter D. Sherer. 1990. “Assessing Employee Attitudes under Two-Tier Pay Plans.” Industrial and Labor Relations Review. Vol. 43, No. 2 (January), pp. 223-244.

Cappelli, Peter and Nikolai Rogovsky. 1998. "Employee Involvement and Organizational Citizenship: Implications for Labor Law Reform and 'Lean production." Industrial \& Labor Relations Review. Vol. 51, No. 4 (July), pp. 633-653.

Cotton, John L. 1993. Employee Involvement: Methods for Improving Performance and Work Attitudes. Newbury Park, CA: Sage Publications.

Cyert, Richard M. and David C. Mowery. (eds.) 1987. Technology and Employment. Washington, D.C.: National Academy of Sciences.

Danzinger, Sheldon and Peter Gottschalk. 1994. Uneven Tides: Rising Inequality in America. New York: Russell Sage.

DiNardo, John E. and Jorn-Steffan Pischke. 1997. "The Return to Computer Use Revisited: Have Pencils Changed the Wage Structure Too?" The Quarterly Journal of Economics. Vol. 112, No. 1 (February), pp. 291303.

Doms, Mark, Timothy Dunne, and Kenneth R. Troshe. 1997. "Workers, Wages and Technology. Quarterly Journal of Economics. 112 (1): 253-290, January.

Dunne, Timothy and James A. Schmitz, Jr. 1993. "Wages, Employment Structure, and Employer Size-Wage Premia: Their Relationship to Advanced Technology Usage at U.S. Manufacturing Establishments." 
Durkheim, Emile. 1964. Division of Labor in Society. Glencoe, Illinois: Free Press.

Edwards, Richard, Michael Reich, and David Gordon. 1979. Labor Market Segmentation. New York: Basic Books.

EQW. 1995. "First Findings: Results of the EQW Employer Survey." Philadelphia, PA: National Center on the Educational Quality of the Workforce (EQW). 1995.

Ehrenberg, Ronald G. and Robert S. Smith. 1988. Modern Labor economics: Theory and Public Policy. Glenview, IL: Scott, Foresman.

Flynn, Patricia M. 1988. Facilitating Technological Change: The Human Resource Challenge. Cambridge, Massachusetts: Ballinger.

Goldin, Claudia and Lawrence F. Katz. 1995. "The Decline of Non-Competing Groups: Changes in the Premium to Education, 1890-1940." Harvard University Working Paper, July 23.

Handel, Michael and Maury Gittleman. 1999. "Is There a Wage Payoff to Innovative Work Practices? Presented at Jeroome Levy Economics Institute Workshop on Earning Inequality, Technology, and Institutions, June 8-10 1999.

Hirshhorn, Larry. 1984. Beyond Mechanization: Work and Technology in a Post-Industrial Age. Cambridge, Massachusetts: Massachusetts Institute of Technology Press.

Hobsbawm, Eric J. 1964. "The Labor Aristocracy in the 19th Century." Laboring Men. Ed. Eric J. Hobsbawm. New York: Basic Books.

Howell, D.R. and E.N. Wolff. 1991. "Trends in the Growth and Distribution of Skills in the U.S. Workplace, 1960-1985." Industrial and Labor Relations Review. April, pp. 496-502.

Ichniowski, Casey, Kathryn Shaw, and Giovanna Prennushi. 1997. "The Effects of Human Resource Management Practices on Productivuty: A Study of Steel Finishing Lines." American Economic Review. 87(3), 291-313, January.

Huselid, Mark A. and Brian E. Becker. 1996. "Methodological Issues in Cross-Sectional and Panel Estimates of the Human Resource-Firm Performance Link." Industrial Relations, 35(3), July: 400-422.

Hyman, Richard and Wolfgang Streek. (eds.) 1988. New Technology and Industrial Relations. Oxford, England: Blackwell.

Judge, G.G., W.E. Griffiths, R.C. Hill, and T.C. Lee. 1981. The Theory and Practice of Econometrics. New York: John Wiley.

Katz, Harry C., Thomas A. Kochan, and Kenneth R. Gobeille. 1983. "Industrial Relations Performance, Economic Performance, and QWL Programs: An Interplant Analysis." Industrial and Labor Relations Review, 37: 3-17.

Katz, Harry C., Thomas A. Kochan, and Mark A. Weber. 1985. "Assessing the Effects of Industrial Relations Systems and Efforts to Improve the Quality of Working Life on Organizational Effectiveness." 
Academy of Management Journal, 28: 509-526.

Kennedy, Peter. 1997. A Guide to Econometrics. Cambridge, MA: MIT Press.

Kelley, Maryellen. 1989. "Unionization and Job Design Under Programmable Automation." Industrial Relations. Vol. 28, No. 2 (Spring): 174-187.

Kerr, Clark, John T. Dunlop, Frederick Harbison, and Charles Myers. 1960. Industrialism and Industrial Man. Oxford, England: Oxford University Press.

Krashinsky, Harry A. 2000. "Do Marital Status and Computer Usage Really Change the Wage Structure? Evidence from a Sample of Twins.” Princeton university Industrial Relations Section Working Paper \#439, June 2000.

Krueger, Alan B. 1993. "How Computers Have Changed the Wage Structure: Evidence from Microdata, 19841989." Quarterly Journal of Economics, February, pp.33-60.

Leigh, Duane E.and Kirk D. Gifford. 1999. "Workplace Transformation and Worker Upskilling: The Perspective of Individual Workers.” Industrial Relations Vol. 38, No. 2 (April), pp. 174-191.

Leonard, Jonathan S., Benoit Mulkay, and Marc Van Audenrode. 1999. Compensation Policies and Firm Productivity. In John C. Haltiwanger, Julia I. Lane, James R. Spletzer, Jules J.M. Theeuwes, and Kenneth R. Troske (eds.). The Creation and Analysis of Employer-Employee Matched Data. Amsterdam: North Holland

Levin, Henry M., Russell Rumberger, and Christine Finnan. 1990. "Escalating Skill Requirements or Different Skill Requirements?" Paper presented at Conference on Changing Occupational Skill Requirements: Gathering and Assessing the Evidence. 5-6 June. Providence, Rhode Island: Brown University.

Levy, Frank and Richard Murnane. 1992. "U.S. Earnings Levels and Earnings Inequality: A Review of Recent Trends and Proposed Explanations." Journal of Economic Literature, Vol. 30, No. 3 (September), pp. 13331381.

Lynch, Lisa and Sandra E. Black. 1995. "Beyond the Incidence of Employer Provided Training: Evidence from a National Employers Survey." Cambridge, MA: NBER Working Paper. Lynch, Lisa and Sandra E. Black. 2000. "What's Driving the new Economy: The Benefits of Workplace Innovation." Cambridge, MA: NBER Working Paper W7479.

MacDuffie, John Paul. 1995. "Human Resource Bundles and Manufacturing Performance: Organizational Logic and Flexible Production Systems in the World Auto Industry." Industrial and Labor Relations Review, 48(2), January: 197-221.

Marglin, Stephen A. 1974. "What Do Bosses Do? The Origins of Hierarchy in Capitalist Production." Review of Radical Political Economics 4, pp. 60-112.

Mincer, Jacob. 1991. "Human Capital, Technology, and the Wage Structure: What Do Time Series Show?" NBER Working Paper No. 3581.

Mishel, Lawrence and Jared Bernstein. 1994. "Is the Technological Black Box Empty? An Empirical Examination of the Impact of Technology on Wage Inequality and the Employment Structure." Washington, D.C.: Economic Policy Institute Working Paper. 
Mueller, Eva, Judith Hybels, Jay Schmiedeskamp, John Sonquist, and Charles Staelin. 1969. "Technological Advance in an Expanding Economy: Its Impact on a Cross-Section of the Labor Force." Ann Arbor, Michigan: Survey Research Center.

National Academy of Sciences. 1986. Human Resource Practices for Implementing Advanced Manufacturing. Washington, D.C.: National Academy Press.

National Center on Education and the Economy. 1990. America's Choice: High Skills or Low Wages? Rochester, NY: National Center.

Noble, David F. 1977. Forces of Production: A Social History of Industrial Automation. New York: Alfred A. Knopf.

Office of Technology Assessment. 1990. Worker Training. U.S. Congress: Government Printing Office.

Osterman, Paul. 2000. "Work Reorganization in an Era of Restructuring." Industrial and Labor Relations Review 53:2.

Seigel, Donald S. 1999. Skill-Based Technological Change: Evidence from a Firm-Level Survey. Kalamazoo, MI: W.E. Upjohn Institute.

Veblin, Thornsten. 1914. The Instinct of Workmanship. New York: Viking.

Walker, Charles R. and Robert H. Guest. 1952. Man on the Assembly Line. Cambridge, Massachusetts: Harvard University Press.

Woodward, Joan. 1965. Industrial Organization: Theory and Practice. Oxford: Oxford University Press.

Womack, James, Daniel Jones, and Daniel Roos. 1990. The Machine that Changed the World. New York: Rawson-MacMillan.

Zuboff, Shoshana. 1988. In the Age of the Smart Machine. New York: Basic Books. 
Table 2: Means and Standard Deviations

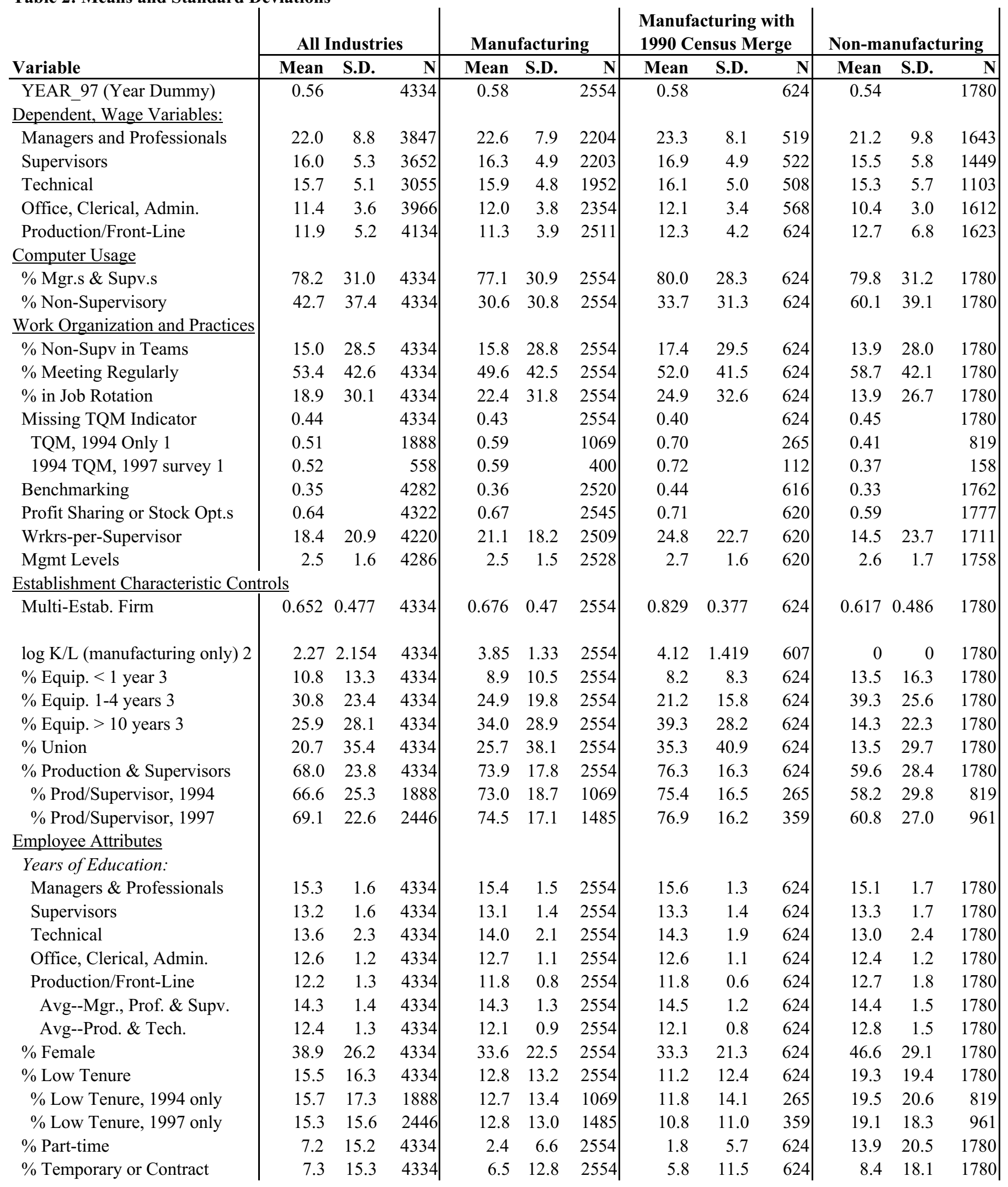


Table 2: Means and Standard Deviations, continued

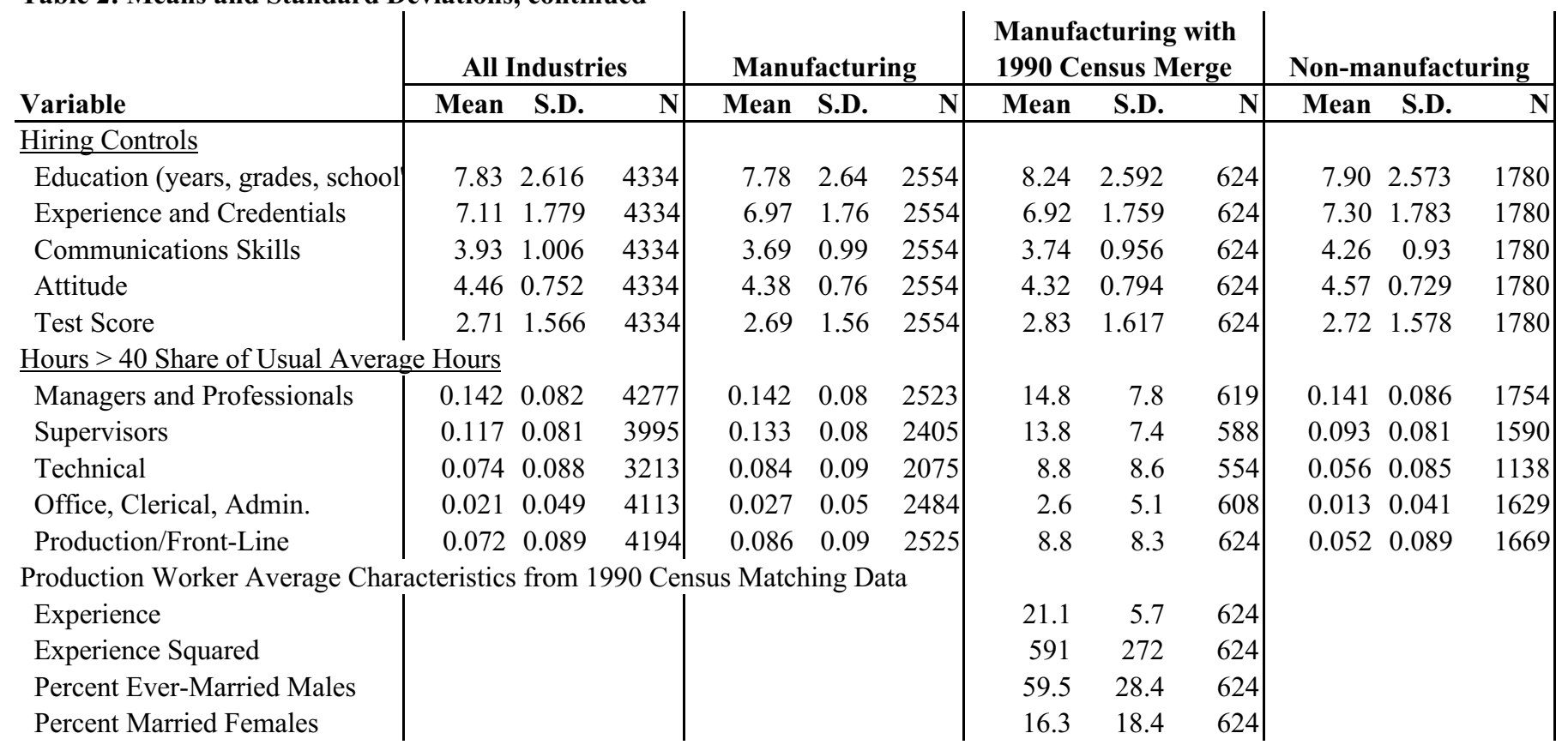

$\underline{\text { Notes }}$

1. In the regressions, the 1994 TQM response is used for 1997 observations in the panel, and set to zero for 1997 observations not in the panel. 2. Log K/L is zero for non-manufacturing establishments. 3. The equipment stock age distribution variables are interacted with a dummy for non-manufacturing in the regressions combining manufacturing and non-manufacturing.

Means for the industry and size dummy variables are not reported to avoid additional data disclosure analyzes and requirements. 
Table 3: Pooled, 1994 and 1997, Sample Pay Regressions.

Arnie, see "WBP_D.LOG" for cell sizes for dummy variables with coefficients reported here.

Managers and Professionals

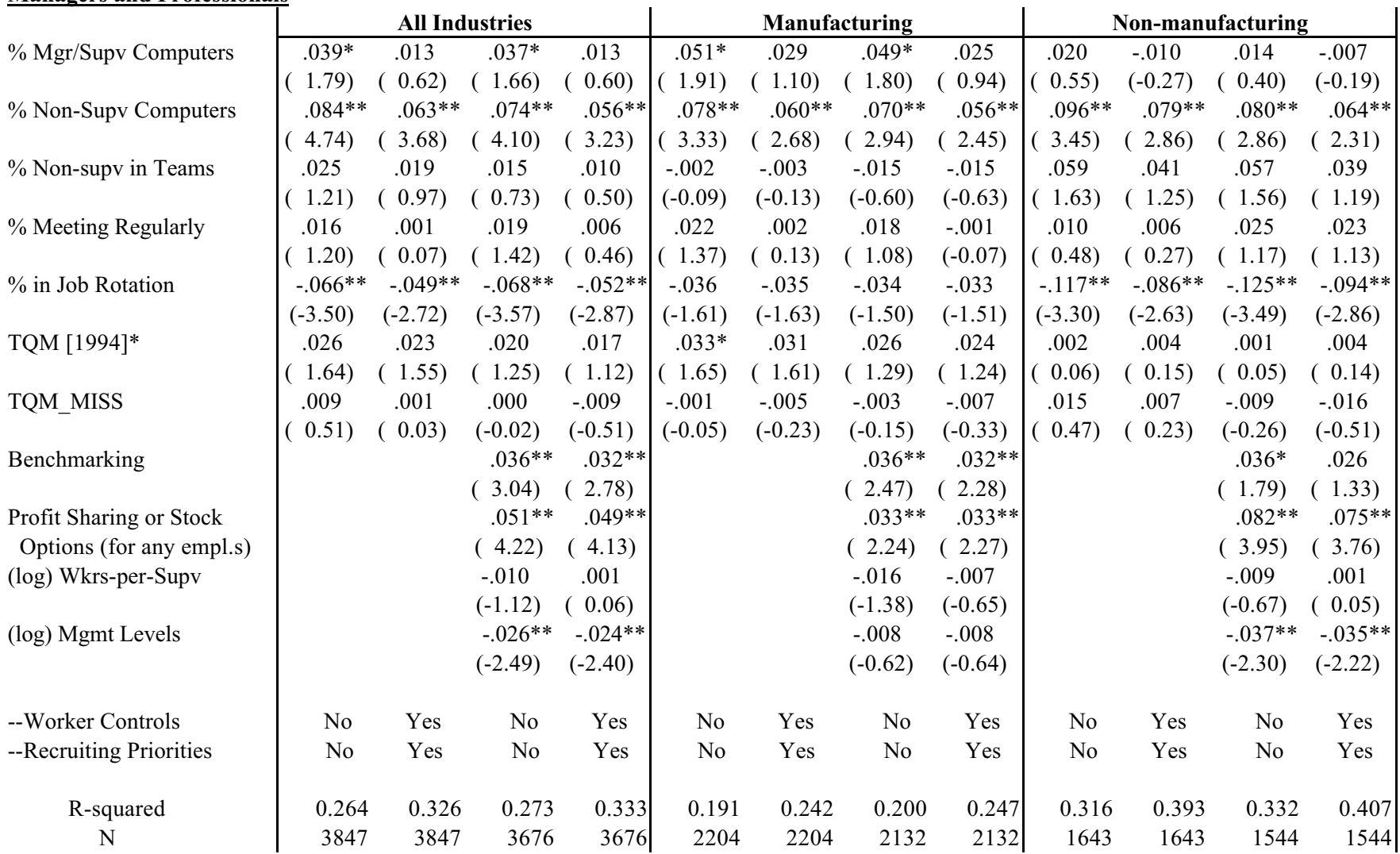

\section{$\underline{\text { Supervisors }}$}

\% Mgr/Supv Computers

$\%$ Non-Supv Computers

$\%$ Non-supv in Teams

$\%$ Meeting Regularly

$\%$ in Job Rotation

TQM [1994]*

TQM_MISS

Benchmarking

Profit Sharing or Stock Options (for any empl.s) (log) Wkrs-per-Supv

(log) Mgmt Levels

--Worker Controls

--Recruiting Priorities

$$
\text { R-squared }
$$$$
\mathrm{N}
$$

\begin{tabular}{|c|c|c|c|c|c|c|c|c|c|c|c|}
\hline \multicolumn{4}{|c|}{ All Industries } & \multicolumn{4}{|c|}{ Manufacturing } & \multicolumn{4}{|c|}{ Non-manufacturing } \\
\hline $.063 * *$ & $.042 * *$ & $.046^{* *}$ & $.028^{*}$ & $.066^{* *}$ & $.049 * *$ & $.054 * *$ & $.036^{*}$ & $.056^{*}$ & .025 & .033 & .007 \\
\hline$(3.60)$ & $(2.54)$ & $(2.62)$ & $(1.65)$ & $(3.23)$ & $(2.53)$ & $(2.59)$ & $(1.81)$ & ( 1.83$)$ & $(0.87)$ & $(1.05)$ & $(0.23)$ \\
\hline $.074 * *$ & $.048 * *$ & $.069 * *$ & $.048 * *$ & $.101 * *$ & $.065^{* *}$ & $.096^{* *}$ & $.064 * *$ & $.054 * *$ & $.040 *$ & $.048 * *$ & $.039^{*}$ \\
\hline$(4.90)$ & $(3.38)$ & $(4.55)$ & $(3.35)$ & $(5.10)$ & $(3.50)$ & $(4.76)$ & $(3.43)$ & $(2.25)$ & $(1.75)$ & $(2.01)$ & ( 1.68$)$ \\
\hline $.051 * *$ & $.036^{* *}$ & $.030^{*}$ & .017 & .033 & .023 & .011 & .003 & $.069 * *$ & .045 & .052 & .030 \\
\hline$(2.85)$ & $(2.20)$ & ( 1.66$)$ & ( 1.06$)$ & $(1.58)$ & ( 1.15$)$ & $(0.55)$ & $(0.15)$ & $(2.11)$ & $(1.56)$ & ( 1.59$)$ & ( 1.03$)$ \\
\hline $.019 *$ & .007 & .016 & .005 & $.032 * *$ & .012 & $.025^{*}$ & .008 & -.002 & -.003 & .002 & -.001 \\
\hline$(1.71)$ & $(0.67)$ & $(1.42)$ & $(0.46)$ & $(2.37)$ & $(0.91)$ & $(1.85)$ & ( 0.59$)$ & $(-0.10)$ & $(-0.18)$ & $(0.13)$ & $(-0.05)$ \\
\hline$-.053 * *$ & $-.033 * *$ & $-.055 * *$ & $-.035 * *$ & $-.044 * *$ & -.026 & $-.048 * *$ & $-.030^{*}$ & $-.079 * *$ & $-.066 * *$ & $-.074 * *$ & $-.062 * *$ \\
\hline$(-3.27)$ & $(-2.14)$ & $(-3.37)$ & $(-2.22)$ & $(-2.38)$ & $(-1.47)$ & $(-2.54)$ & $(-1.67)$ & $(-2.48)$ & $(-2.24)$ & $(-2.30)$ & $(-2.06)$ \\
\hline $.023 *$ & .019 & .014 & .009 & .023 & .019 & .015 & .012 & .016 & .012 & .007 & .002 \\
\hline ( 1.74$)$ & $(1.50)$ & ( 1.01$)$ & $(0.72)$ & ( 1.38$)$ & ( 1.18$)$ & $(0.91)$ & $(0.72)$ & $(0.69)$ & $(0.55)$ & $(0.29)$ & $(0.10)$ \\
\hline-.010 & -.014 & -.017 & -.023 & -.021 & -.026 & -.023 & -.028 & .016 & .012 & -.005 & -.010 \\
\hline$(-0.63)$ & $(-0.95)$ & $(-1.12)$ & $(-1.53)$ & $(-1.14)$ & $(-1.45)$ & $(-1.21)$ & $(-1.50)$ & $(0.61)$ & $(0.49)$ & $(-0.20)$ & $(-0.42)$ \\
\hline & & $.047 * *$ & $.044 * *$ & & & $.043 * *$ & $.039 * *$ & & & $.053 * *$ & $.049 * *$ \\
\hline & & $(4.75)$ & $(4.65)$ & & & $(3.56)$ & $(3.42)$ & & & $(3.08)$ & $(3.05)$ \\
\hline & & $.054 * *$ & $.046^{* *}$ & & & $.036^{* *}$ & $.028^{* *}$ & & & $.077 * *$ & $.067 * *$ \\
\hline & & $(5.10)$ & $(4.68)$ & & & $(2.80)$ & $(2.25)$ & & & $(4.19)$ & ( 3.94$)$ \\
\hline & & .008 & $.020 * *$ & & & .003 & $.020 * *$ & & & .009 & .016 \\
\hline & & $(1.11)$ & $(2.98)$ & & & $(0.35)$ & $(2.17)$ & & & $(0.82)$ & $(1.49)$ \\
\hline & & $-.027 * *$ & $-.027 * *$ & & & $-.023 * *$ & $-.024 * *$ & & & $-.030^{* *}$ & $-.026^{* *}$ \\
\hline & & $(-3.00)$ & $(-3.21)$ & & & $(-2.00)$ & $(-2.25)$ & & & $(-2.12)$ & $(-1.97)$ \\
\hline No & Yes & No & Yes & No & Yes & No & Yes & No & Yes & No & Yes \\
\hline No & Yes & No & Yes & No & Yes & No & Yes & No & Yes & No & Yes \\
\hline 0.364 & 0.437 & 0.374 & 0.444 & 0.296 & 0.368 & 0.304 & 0.377 & 0.430 & 0.511 & 0.446 & 0.521 \\
\hline 3651 & 3651 & 3486 & 3486 & 2203 & 2203 & 2123 & 2123 & 1448 & 1448 & 1363 & 1363 \\
\hline
\end{tabular}


Table 3: Pooled, 1994 and 1997, Sample Pay Regressions (continued).

Technical and Technical Support Workers

\begin{tabular}{|c|c|c|c|c|c|c|c|c|c|c|c|c|}
\hline \multirow[b]{2}{*}{$\%$ Mgr/Supv Computers } & \multicolumn{4}{|c|}{ All Industries } & \multicolumn{4}{|c|}{ Manufacturing } & \multicolumn{4}{|c|}{ Non-manufacturing } \\
\hline & $.076^{* *}$ & $.044 * *$ & $.068 * *$ & $.036^{*}$ & $.076 * *$ & $.039 *$ & $.070 * *$ & .034 & $.073 *$ & .044 & .064 & .035 \\
\hline & $(3.61)$ & $(2.20)$ & $(3.15)$ & $(1.76)$ & $(3.15)$ & $(1.73)$ & $(2.82)$ & $(1.45)$ & $(1.75)$ & $(1.13)$ & $(1.50)$ & $(0.89)$ \\
\hline \multirow[t]{2}{*}{$\%$ Non-Supv Computers } & $.045^{* *}$ & .027 & $.041 * *$ & $.030^{*}$ & $.046^{* *}$ & .026 & .037 & .023 & .052 & .040 & .053 & .046 \\
\hline & $(2.41)$ & $(1.59)$ & $(2.19)$ & $(1.71)$ & $(2.10)$ & $(1.27)$ & ( 1.63$)$ & ( 1.09$)$ & $(1.55)$ & $(1.32)$ & $(1.56)$ & ( 1.49$)$ \\
\hline \multirow[t]{2}{*}{$\%$ Non-supv in Teams } & $.034^{*}$ & .017 & .024 & .008 & .030 & .013 & .019 & .001 & .045 & .016 & .042 & .017 \\
\hline & $(1.90)$ & $(0.99)$ & $(1.30)$ & $(0.45)$ & $(1.47)$ & $(0.68)$ & $(0.90)$ & $(0.06)$ & $(1.28)$ & $(0.50)$ & $(1.13)$ & $(0.50)$ \\
\hline \multirow[t]{2}{*}{$\%$ Meeting Regularly } & .015 & .011 & .011 & .009 & $.027^{*}$ & $.024 *$ & .023 & .023 & .011 & -.001 & .010 & -.005 \\
\hline & $(1.16)$ & $(0.92)$ & $(0.84)$ & ( 0.69$)$ & $(1.76)$ & ( 1.68$)$ & $(1.49)$ & $(1.58)$ & $(0.43)$ & $(-0.04)$ & $(0.37)$ & $(-0.20)$ \\
\hline \multirow[t]{2}{*}{$\%$ in Job Rotation } & $-.051 * *$ & -.024 & $-.054 * *$ & $-.031 *$ & $-.041 * *$ & -.025 & $-.041^{*}$ & -.027 & -.068 & -.038 & $-.080^{*}$ & -.053 \\
\hline & $(-2.72)$ & $(-1.40)$ & $(-2.83)$ & $(-1.73)$ & $(-2.03)$ & $(-1.30)$ & $(-1.97)$ & $(-1.38)$ & $(-1.55)$ & $(-1.01)$ & $(-1.84)$ & $(-1.41)$ \\
\hline \multirow[t]{2}{*}{ TQM [1994]* } & .018 & .016 & .017 & .013 & .020 & .015 & .016 & .010 & .013 & .023 & .017 & .025 \\
\hline & $(1.21)$ & $(1.11)$ & ( 1.13$)$ & $(0.89)$ & ( 1.16$)$ & $(0.94)$ & $(0.93)$ & $(0.62)$ & $(0.44)$ & $(0.83)$ & $(0.56)$ & $(0.90)$ \\
\hline \multirow[t]{2}{*}{ TQM_MISS } & .005 & .004 & .000 & -.002 & -.004 & -.006 & -.004 & -.006 & .032 & .032 & .010 & .011 \\
\hline & $(0.32)$ & $(0.25)$ & $(0.03)$ & $(-0.10)$ & $(-0.18)$ & $(-0.31)$ & $(-0.20)$ & $(-0.33)$ & $(0.95)$ & $(1.00)$ & $(0.29)$ & $(0.34)$ \\
\hline \multirow[t]{2}{*}{ Benchmarking } & & & $.031^{* *}$ & $.030 * *$ & & & $.032 * *$ & $.029 * *$ & & & .032 & .029 \\
\hline & & & $(2.73)$ & $(2.82)$ & & & $(2.51)$ & $(2.46)$ & & & $(1.47)$ & $(1.48)$ \\
\hline Profit Sharing or Stock & & & $.025 * *$ & $.019 *$ & & & .014 & .007 & & & .038 & .034 \\
\hline Options (for any empl.s) & & & $(2.09)$ & ( 1.66$)$ & & & ( 1.03$)$ & $(0.56)$ & & & ( 1.64$)$ & $(1.58)$ \\
\hline (log) Wkrs-per-Supv & & & -.007 & .009 & & & -.016 & -.001 & & & .010 & $.027^{*}$ \\
\hline & & & $(-0.72)$ & $(1.07)$ & & & $(-1.55)$ & $(-0.13)$ & & & $(0.59)$ & $(1.81)$ \\
\hline (log) Mgmt Levels & & & -.011 & -.013 & & & .001 & .000 & & & -.024 & -.025 \\
\hline & & & $(-1.03)$ & $(-1.39)$ & & & $(0.12)$ & $(0.03)$ & & & $(-1.29)$ & $(-1.44)$ \\
\hline --Worker Controls & No & Yes & No & Yes & No & Yes & No & Yes & No & Yes & No & Yes \\
\hline --Recruiting Priorities & No & Yes & No & Yes & No & Yes & No & Yes & No & Yes & No & Yes \\
\hline R-squared & 0.251 & 0.350 & 0.250 & 0.348 & 0.253 & 0.341 & 0.256 & 0.340 & 0.257 & 0.390 & 0.256 & 0.395 \\
\hline $\mathrm{N}$ & 3053 & 3053 & 2922 & 2922 & 1951 & 1951 & 1876 & 1876 & 1102 & 1102 & 1046 & 1046 \\
\hline
\end{tabular}

Office Workers

$\% \mathrm{Mgr} / \mathrm{Supv}$ Computers

\% Non-Supv Computers

$\%$ Non-supv in Teams

$\%$ Meeting Regularly

$\%$ in Job Rotation

TQM [1994]*

TQM MISS

Benchmarking

Profit Sharing or Stock Options (for any empl.s) (log) Wkrs-per-Supv

(log) Mgmt Levels

--Worker Controls

--Recruiting Priorities

R-squared $\mathrm{N}$

\begin{tabular}{|c|c|c|c|c|c|c|c|c|c|c|c|}
\hline \multicolumn{4}{|c|}{ All Industries } & \multicolumn{4}{|c|}{ Manufacturing } & \multicolumn{4}{|c|}{ Non-manufacturing } \\
\hline $.048 * *$ & $.039 * *$ & $.037 * *$ & $.030 *$ & $.057 * *$ & $.046^{* *}$ & $.043 * *$ & .029 & .036 & .027 & .029 & .028 \\
\hline$(3.11)$ & $(2.53)$ & $(2.34)$ & ( 1.90$)$ & $(2.87)$ & $(2.35)$ & $(2.13)$ & $(1.50)$ & ( 1.45$)$ & ( 1.09$)$ & ( 1.12$)$ & ( 1.11$)$ \\
\hline $.041 * *$ & $.028 * *$ & $.038 * *$ & $.029 * *$ & $.066^{* *}$ & $.049 * *$ & $.063 * *$ & $.049 * *$ & .021 & .012 & .016 & .010 \\
\hline$(2.86)$ & $(2.07)$ & $(2.63)$ & $(2.04)$ & $(3.12)$ & $(2.43)$ & $(2.85)$ & $(2.33)$ & ( 1.08$)$ & $(0.61)$ & $(0.81)$ & $(0.49)$ \\
\hline $.036 * *$ & $.027 *$ & $.029 *$ & .020 & .028 & .021 & .024 & .016 & .037 & .026 & .028 & .019 \\
\hline$(2.49)$ & $(1.90)$ & ( 1.97$)$ & ( 1.43$)$ & ( 1.49$)$ & ( 1.12$)$ & $(1.25)$ & $(0.87)$ & ( 1.62$)$ & ( 1.17$)$ & $(1.18)$ & $(0.82)$ \\
\hline $.021 * *$ & .010 & .016 & .006 & .008 & -.008 & .001 & -.014 & $.037 * *$ & $.033 * *$ & $.036 * *$ & $.032 * *$ \\
\hline$(2.07)$ & ( 1.05$)$ & $(1.50)$ & $(0.61)$ & $(0.57)$ & $(-0.62)$ & $(0.05)$ & $(-1.01)$ & $(2.43)$ & $(2.24)$ & $(2.33)$ & $(2.18)$ \\
\hline$-.029 * *$ & -.017 & $-.032 * *$ & -.020 & -.020 & -.007 & -.024 & -.013 & $-.051 * *$ & $-.043 * *$ & $-.052 * *$ & $-.043 *$ \\
\hline$(-2.16)$ & $(-1.30)$ & $(-2.32)$ & $(-1.46)$ & $(-1.17)$ & $(-0.44)$ & $(-1.39)$ & $(-0.73)$ & $(-2.21)$ & $(-2.00)$ & $(-2.24)$ & $(-1.95)$ \\
\hline .018 & .014 & .011 & .007 & .015 & .011 & .005 & .002 & .021 & .018 & .017 & .015 \\
\hline ( 1.53$)$ & $(1.25)$ & $(0.91)$ & $(0.64)$ & $(0.94)$ & $(0.69)$ & $(0.33)$ & $(0.12)$ & ( 1.18$)$ & ( 1.07$)$ & $(0.96)$ & $(0.88)$ \\
\hline-.005 & -.004 & -.011 & -.010 & -.022 & -.022 & -.027 & -.027 & .030 & $.032 *$ & .027 & .031 \\
\hline$(-0.39)$ & $(-0.32)$ & $(-0.78)$ & $(-0.73)$ & $(-1.23)$ & $(-1.25)$ & $(-1.50)$ & $(-1.52)$ & ( 1.52$)$ & ( 1.65$)$ & ( 1.28$)$ & $(1.53)$ \\
\hline & & $.027 * *$ & $.022 * *$ & & & $.033 * *$ & $.028 * *$ & & & .015 & .010 \\
\hline & & ( 2.97$)$ & $(2.48)$ & & & $(2.79)$ & $(2.46)$ & & & $(1.11)$ & $(0.71)$ \\
\hline & & $.041 * *$ & $.036^{* *}$ & & & $.033^{* *}$ & $.027 * *$ & & & $.048 * *$ & $.040 * *$ \\
\hline & & $(4.43)$ & $(3.92)$ & & & $(2.70)$ & $(2.27)$ & & & $(3.28)$ & $(2.81)$ \\
\hline & & -.001 & .005 & & & .000 & .008 & & & -.003 & .002 \\
\hline & & $(-0.23)$ & $(0.90)$ & & & $(-0.05)$ & $(0.96)$ & & & $(-0.35)$ & $(0.27)$ \\
\hline & & -.007 & -.007 & & & .003 & .000 & & & -.017 & -.014 \\
\hline & & $(-0.86)$ & $(-0.97)$ & & & $(0.24)$ & $(-0.04)$ & & & $(-1.59)$ & $(-1.36)$ \\
\hline No & Yes & No & Yes & No & Yes & No & Yes & No & Yes & No & Yes \\
\hline No & Yes & No & Yes & No & Yes & No & Yes & No & Yes & No & Yes \\
\hline 0.297 & 0.350 & 0.302 & 0.355 & 0.248 & 0.300 & 0.247 & 0.301 & 0.299 & 0.368 & 0.317 & 0.380 \\
\hline 3966 & 3966 & 3775 & 3775 & 2354 & 2354 & 2262 & 2262 & 1612 & 1612 & 1513 & 1513 \\
\hline
\end{tabular}


Table 3: Pooled, 1994 and 1997, Sample Pay Regressions (continued).

Production/Front-line Workers

$\% \mathrm{Mgr} / \mathrm{Supv}$ Computers

\begin{tabular}{|c|c|c|c|c|c|c|c|c|c|c|c|}
\hline \multicolumn{4}{|c|}{ All Industries } & \multicolumn{4}{|c|}{ Manufacturing } & \multicolumn{4}{|c|}{ Non-manufacturing } \\
\hline $.089 * *$ & $.065^{* *}$ & $.080 * *$ & $.059 * *$ & $.086^{* *}$ & $.063 * *$ & $.075^{* *}$ & $.051 * *$ & $.106^{* *}$ & $.066^{* *}$ & $.102 * *$ & $.071 * *$ \\
\hline$(4.86)$ & $(3.91)$ & $(4.35)$ & $(3.54)$ & $(4.32)$ & $(3.59)$ & $(3.74)$ & $(2.87)$ & $(3.04)$ & $(2.02)$ & $(2.88)$ & $(2.17)$ \\
\hline $.087 * *$ & $.049 * *$ & $.079 * *$ & $.047 * *$ & $.096^{* *}$ & $.054 * *$ & $.084^{* *}$ & $.049 * *$ & $.085^{* *}$ & .043 & $.085 * *$ & $.047^{*}$ \\
\hline$(4.97)$ & $(3.13)$ & $(4.52)$ & $(2.99)$ & $(4.64)$ & $(2.98)$ & ( 3.99$)$ & $(2.68)$ & $(2.91)$ & $(1.61)$ & $(2.91)$ & ( 1.73$)$ \\
\hline $.051 * *$ & $.028 *$ & $.045^{* *}$ & .025 & $.064 * *$ & $.051 * *$ & $.060 * *$ & $.047 * *$ & .024 & -.017 & .012 & -.022 \\
\hline$(2.73)$ & $(1.70)$ & $(2.35)$ & $(1.47)$ & $(3.22)$ & $(2.87)$ & $(2.93)$ & $(2.54)$ & $(0.68)$ & $(-0.55)$ & $(0.32)$ & $(-0.69)$ \\
\hline $.046^{* *}$ & $.024 * *$ & $.040 * *$ & $.020 *$ & $.059 * *$ & $.029 * *$ & $.052 * *$ & $.025 * *$ & .025 & .011 & .019 & .007 \\
\hline$(3.84)$ & $(2.32)$ & $(3.25)$ & $(1.89)$ & $(4.52)$ & $(2.50)$ & $(3.90)$ & $(2.12)$ & $(1.11)$ & $(0.56)$ & $(0.81)$ & $(0.33)$ \\
\hline$-.063 * *$ & $-.035 * *$ & $-.059 * *$ & $-.033 * *$ & $-.081 * *$ & $-.039 * *$ & $-.081 * *$ & $-.044 * *$ & -.057 & -.040 & -.048 & -.029 \\
\hline$(-3.78)$ & $(-2.41)$ & $(-3.52)$ & $(-2.23)$ & $(-4.58)$ & $(-2.50)$ & $(-4.57)$ & $(-2.78)$ & $(-1.63)$ & $(-1.35)$ & $(-1.30)$ & $(-0.94)$ \\
\hline $.038 * *$ & $.036^{* *}$ & $.030^{*}$ & $.027 * *$ & $.045^{* *}$ & $.042 * *$ & $.035^{* *}$ & $.033 * *$ & .022 & .026 & .01 & .01 \\
\hline$(2.55)$ & $(2.73)$ & ( 1.95$)$ & $(2.06)$ & $(2.69)$ & $(2.99)$ & $(2.07)$ & $(2.30)$ & $(0.77)$ & ( 1.03$)$ & $(0$. & $(0.72)$ \\
\hline .015 & .007 & .006 & .000 & .025 & .018 & .017 & .013 & -.005 & .000 & -.017 & -.009 \\
\hline$(0.90)$ & $(0.50)$ & $(0.35)$ & $(0.02)$ & $(1.38)$ & $(1.15)$ & $(0.96)$ & $(0.83)$ & $(-0.15)$ & $(-0.01)$ & $(-0.47)$ & $(-0.30)$ \\
\hline & & $.034 * *$ & $.029 * *$ & & & $.033 * *$ & $.029 * *$ & & & .035 & .027 \\
\hline & & $(3.11)$ & $(2.94)$ & & & $(2.82)$ & $(2.79)$ & & & $(1.61)$ & ( 1.38$)$ \\
\hline & & $.053 * *$ & $.042 * *$ & & & $.045^{* *}$ & $.034 * *$ & & & $.068 * *$ & $.051^{* *}$ \\
\hline & & $(4.73)$ & $(4.15)$ & & & ( 3.69$)$ & $(3.13)$ & & & $(3.15)$ & $(2.63)$ \\
\hline & & $-.034 * *$ & $-.013^{*}$ & & & $-.029 * *$ & -.004 & & & $-.046^{* *}$ & -.022 \\
\hline & & $(-3.99)$ & $(-1.73)$ & & & $(-3.00)$ & $(-0.45)$ & & & $(-3.22)$ & $(-1.64)$ \\
\hline & & $-.037 * *$ & $-.031 * *$ & & & $-.031 * *$ & $-.028 * *$ & & & $-.039 * *$ & $-.028 *$ \\
\hline & & $(-3.89)$ & $(-3.75)$ & & & $(-2.96)$ & $(-3.00)$ & & & $(-2$ & $(-1.88)$ \\
\hline No & Yes & No & Yes & No & Yes & No & Yes & No & Yes & No & Yes \\
\hline No & Yes & No & Yes & No & Yes & No & Yes & No & Yes & No & Yes \\
\hline 0.418 & 0.538 & 0.429 & 0.544 & 0.425 & 0.5 & & & 0.429 & & & 0.557 \\
\hline 4125 & 4125 & 3917 & 3917 & 2510 & 2510 & 2402 & 2402 & 1615 & 1615 & 1515 & 1515 \\
\hline
\end{tabular}

Manufacturing Production Workers, 1990 Census Merger Sample.

\begin{tabular}{|c|c|c|c|c|c|c|}
\hline$\%$ Mgr/Supv Computers & .069 & .050 & .033 & .053 & .040 & .029 \\
\hline & $(1.53)$ & $(1.20)$ & $(0.83)$ & $(1.25)$ & $(1.01)$ & $(0.74)$ \\
\hline$\%$ Non-Supv Computers & $.113^{* *}$ & $.093^{* *}$ & $.089 * *$ & $.100 * *$ & $.080 * *$ & $.077 * *$ \\
\hline & $(2.85)$ & $(2.48)$ & $(2.50)$ & $(2.52)$ & $(2.15)$ & $(2.19)$ \\
\hline$\%$ Non-supv in Teams & .068 & .040 & .024 & $.108 * *$ & .066 & .051 \\
\hline & $(1.50)$ & $(0.97)$ & $(0.61)$ & $(2.36)$ & ( 1.59$)$ & $(1.29)$ \\
\hline \% Meeting Regularly & $.075 * *$ & $.049 * *$ & $.049 * *$ & $.074 * *$ & $.055 * *$ & $.056^{* *}$ \\
\hline & $(2.70)$ & $(2.07)$ & $(2.14)$ & $(2.69)$ & $(2.30)$ & $(2.44)$ \\
\hline$\%$ in Job Rotation & -.035 & -.017 & -.007 & -.043 & -.029 & -.018 \\
\hline & $(-0.92)$ & $(-0.48)$ & $(-0.20)$ & $(-1.11)$ & $(-0.83)$ & $(-0.53)$ \\
\hline TQM [1994]* & .011 & -.003 & -.015 & .009 & -.010 & -.019 \\
\hline & $(0.31)$ & $(-0.08)$ & $(-0.51)$ & $(0.28)$ & $(-0.34)$ & $(-0.68)$ \\
\hline TQM_MISS & .013 & -.011 & -.013 & .000 & -.024 & -.023 \\
\hline & $(0.34)$ & $(-0.31)$ & $(-0.37)$ & $(0.01)$ & $(-0.70)$ & $(-0.69)$ \\
\hline Benchmarking & & & & -.004 & .005 & -.002 \\
\hline & & & & $(-0.18)$ & $(0.25)$ & $(-0.13)$ \\
\hline Profit Sharing or Stock & & & & .009 & .008 & .012 \\
\hline Options (for any empl.s) & & & & $(0.37)$ & $(0.36)$ & $(0.56)$ \\
\hline (log) Wkrs-per-Supv & & & & $-.054 * *$ & -.021 & -.015 \\
\hline & & & & $(-2.77)$ & $(-1.10)$ & $(-0.82)$ \\
\hline (log) Mgmt Levels & & & & -.015 & -.025 & -.017 \\
\hline & & & & $(-0.72)$ & $(-1.28)$ & $(-0.90)$ \\
\hline --NES Worker Controls & No & Yes & Yes & No & Yes & Yes \\
\hline --Recruiting Priorities & No & Yes & Yes & No & Yes & Yes \\
\hline --1990 Census Controls & No & No & Yes & No & No & Yes \\
\hline R-squ & 0.515 & 0.607 & 0.643 & 0.539 & 0.619 & 0.651 \\
\hline $\mathrm{N}$ & 595 & 595 & 595 & 576 & 576 & 576 \\
\hline
\end{tabular}

$\underline{\text { Notes }}$

t-statistics in parentheses. Coefficients of percentage variables multiplied by 100 . All models also include: two-digit industry (\#10 manufacturing, \#11 non-manufacturing); size category; multi-establishment firm indicator; workforce occupational composition; percentage unionized; the over-40-hours share of usual hours/week; pay-reporting period; and interactions of reporting period with the overtime hours share variables; the age distribution of the capital stock; and a dummy variable for the 1997 survey observations. The manufacturing sector models include the log capital-labor ratio; this variable is equal to zero for non-manufacturing establishments in the all-industries models, where the capital stock age variables are interacted with a dummy variable for non-manufacturing. 
Appendix Table 1: Results for Production/Front-line Worker Wages, Including Control Variables. Arnie, see "WBP_D.LOG" for cell sizes for dummy variables with coefficients reported here.

\begin{tabular}{|c|c|c|c|c|c|c|c|c|c|}
\hline \multirow[b]{2}{*}{ Variable: } & \multirow{2}{*}{$\begin{array}{r}\text { All } \\
\text { Indus- } \\
\text { tries }\end{array}$} & \multicolumn{2}{|c|}{ Manufacturing } & \multirow{2}{*}{$\begin{array}{r}\text { Non- } \\
\text { Man- } \\
\text { ufactur- } \\
\text { ing }\end{array}$} & \multirow[b]{2}{*}{ Variable (continued): } & \multirow{2}{*}{$\begin{array}{r}\text { All } \\
\text { Indus- } \\
\text { tries }\end{array}$} & \multicolumn{2}{|c|}{ Manufacturing } & \multirow{2}{*}{$\begin{array}{r}\text { Non- } \\
\text { Man- } \\
\text { ufactur- } \\
\text { ing }\end{array}$} \\
\hline & & $\begin{array}{r}\text { Full } \\
\text { Sample }\end{array}$ & $\begin{array}{r}\text { w/ } 1990 \\
\text { Census } \\
\text { Controls } \\
\end{array}$ & & & & $\begin{array}{r}\text { Full } \\
\text { Sample }\end{array}$ & $\begin{array}{r}\text { w/ } 1990 \\
\text { Census } \\
\text { Controls }\end{array}$ & \\
\hline \multirow[t]{2}{*}{$\%$ Mgr/Supv Computers } & $.059 * *$ & $.051^{* *}$ & \begin{tabular}{l|}
.029 \\
\end{tabular} & $.071 * *$ & Non-Mfg_\% Equip 1-4 Yr & $.089^{*}$ & & & \\
\hline & $(3.54)$ & $(2.87)$ & $(0.74)$ & $(2.17)$ & & $(1.65)$ & & & \\
\hline \multirow[t]{2}{*}{$\%$ Non-Supv Computers } & $.047 * *$ & $.049 * *$ & $.077 * *$ & $.047^{*}$ & Non-Mfg_\% Equip>10 Yr & $-.112 * *$ & & & \\
\hline & ( 2.99) & $(2.68)$ & ( 2.19) & $(1.73)$ & & $(-2.30)$ & & & \\
\hline \multirow[t]{2}{*}{$\%$ Non-supv in Teams } & .025 & $.047 * *$ & .051 & -.022 & $\%$ Union & $.164 * *$ & $.129 * *$ & $.080 * *$ & $.242 * *$ \\
\hline & $(1.47)$ & $(2.54)$ & $(1.29)$ & $(-0.69)$ & & $(12.07)$ & $(8.91)$ & $(2.74)$ & $(7.80)$ \\
\hline \multirow[t]{2}{*}{$\%$ Meeting Regularly } & $.020 *$ & $.025 * *$ & $.056 * *$ & .007 & $\%$ Prod/Supv & $-.105 * *$ & -.026 & -.050 & $-.124 * *$ \\
\hline & $(1.89)$ & $(2.12)$ & ( 2.44) & $(0.33)$ & & $(-2.67)$ & $(-0.55)$ & $(-0.49)$ & $(-2.14)$ \\
\hline \multirow[t]{2}{*}{$\%$ in Job Rotation } & $-.033 * *$ & $-.044 * *$ & -.018 & -.029 & Yr_1997_\% Prod/Supv & .031 & .017 & -.044 & .011 \\
\hline & $(-2.23)$ & $(-2.78)$ & $(-0.53)$ & $(-0.94)$ & & $(0.67)$ & $(0.31)$ & $(-0.38)$ & $(0.15)$ \\
\hline \multirow[t]{2}{*}{ TQM [1994]* } & $.027 * *$ & $.033 * *$ & -.019 & .019 & Production Wkr Educ & $.081 * *$ & $.044 * *$ & $.051 * *$ & $.092 * *$ \\
\hline & ( 2.06) & $(2.30)$ & $(-0.68)$ & $(0.72)$ & & $(13.62)$ & $(5.72)$ & $(3.05)$ & $(11.66)$ \\
\hline \multirow[t]{2}{*}{ TQM_MISS } & .000 & .013 & -.023 & -.009 & Mgr/Supv Education & $.010 * *$ & $.008^{*}$ & .012 & $.016^{* *}$ \\
\hline & $(0.02)$ & $(0.83)$ & $(-0.69)$ & $(-0.30)$ & & $(2.75)$ & $(1.74)$ & $(1.38)$ & $(2.49)$ \\
\hline \multirow[t]{2}{*}{ Benchmarking } & $.029 * *$ & $.029 * *$ & -.002 & .027 & $\%$ Women & $-.363 * *$ & $-.445^{* *}$ & $-.329 * *$ & $-.255^{* *}$ \\
\hline & ( 2.94) & $(2.79)$ & $(-0.13)$ & $(1.38)$ & & $(-13.76)$ & $(-15.82)$ & $(-4.06)$ & $(-5.00)$ \\
\hline \multirow{4}{*}{$\begin{array}{l}\text { Profit Sharing or Stock } \\
\text { Options (for any empl.s) } \\
(\log ) \text { Wkrs-per-Supv }\end{array}$} & $.042 * *$ & $.034 * *$ & .012 & $.051 * *$ & Turnover Proxy & $-.422 * *$ & $-.555^{* *}$ & $-.354 * *$ & $-.308 * *$ \\
\hline & $(4.15)$ & ( 3.13$)$ & $(0.56)$ & ( 2.63) & & $(-9.16)$ & $(-8.67)$ & $(-2.84)$ & $(-4.73)$ \\
\hline & $-.013^{*}$ & -.004 & -.015 & -.022 & Yr_1997_Turnover & $.144 * *$ & $.205^{* *}$ & -.040 & .101 \\
\hline & $(-1.73)$ & $(-0.45)$ & $(-0.82)$ & $(-1.64)$ & & $(2.63)$ & $(2.66)$ & $(-0.23)$ & $(1.26)$ \\
\hline \multirow[t]{2}{*}{ (log) Mgmt Levels } & $-.031 * *$ & $-.028 * *$ & -.017 & $-.028 *$ & $\%$ Part-time & $-.278 * *$ & -.028 & -.009 & $-.294 * *$ \\
\hline & $(-3.75)$ & $(-3.00)$ & $(-0.90)$ & $(-1.88)$ & & $(-6.67)$ & $(-0.32)$ & $(-0.03)$ & $(-6.07)$ \\
\hline \multirow[t]{2}{*}{ Year_1997 } & .019 & .026 & .111 & .023 & $\%$ Temp/seasonal/leased & $-.072 *$ & $-.079 *$ & -.085 & -.082 \\
\hline & $(0.54)$ & $(0.60)$ & $(1.23)$ & $(0.43)$ & & $(-1.71)$ & $(-1.93)$ & $(-0.96)$ & $(-1.20)$ \\
\hline Weekly Pay Report & .027 & -.006 & .048 & .069 & Rcrt_Education & .002 & .002 & -.006 & .003 \\
\hline & $(0.77)$ & $(-0.14)$ & $(0.45)$ & $(1.14)$ & & $(1.07)$ & $(0.72)$ & $(-1.34)$ & $(0.79)$ \\
\hline Monthly Pay Report & $.129 * *$ & .063 & .095 & .176 & Rcrt_Exp/Cred & $.010 * *$ & $.005^{*}$ & -.008 & $.015 * *$ \\
\hline & $(1.99)$ & $(0.94)$ & $(0.87)$ & $(1.56)$ & & $(3.37)$ & $(1.81)$ & $(-1.23)$ & $(2.76)$ \\
\hline Annual Pay Report & $.115^{* *}$ & $.079 * *$ & $.089 * *$ & $.158 * *$ & Rcrt_Comm. Skill & .004 & .008 & .010 & -.005 \\
\hline & ( 9.07) & ( 5.69$)$ & ( 3.09$)$ & $(7.00)$ & & $(0.66)$ & $(1.38)$ & $(0.82)$ & $(-0.39)$ \\
\hline Overtime_Hourly & $.351 * *$ & $.257 * *$ & .190 & $.389 * *$ & Rcrt_Attitude & $-.014 * *$ & $-.013^{* *}$ & .003 & -.013 \\
\hline & $(4.95)$ & $(3.51)$ & $(1.31)$ & $(2.25)$ & & $(-2.22)$ & $(-1.97)$ & $(0.24)$ & $(-0.90)$ \\
\hline Overtime_Weekly & $-.733 * *$ & -.509 & $-1.673 * *$ & -.788 & Rcrt_Test Score & $.006^{*}$ & $.012 * *$ & .006 & -.002 \\
\hline & $(-2.47)$ & $(-1.50)$ & $(-2.45)$ & $(-1.54)$ & & $(1.95)$ & $(3.66)$ & $(0.81)$ & $(-0.33)$ \\
\hline Overtime_Monthly & $-.937 * *$ & $-.885^{* *}$ & -1.366 & -.630 & Married Men & & & $.204 * *$ & \\
\hline & $(-1.97)$ & $(-2.11)$ & $(-0.97)$ & $(-0.66)$ & & & & ( 2.84) & \\
\hline Overtime_Annual & $-.496 * *$ & $-.399 * *$ & $-.459 * *$ & $-.547 * *$ & Married Women & & & .057 & \\
\hline & $(-5.63)$ & $(-4.02)$ & $(-2.47)$ & $(-3.60)$ & & & & $(0.61)$ & \\
\hline Multi-Establishment & -.011 & .002 & .025 & $-.037^{*}$ & Experience & & & $.021 * *$ & \\
\hline & $(-1.00)$ & $(0.19)$ & $(0.86)$ & $(-1.84)$ & & & & $(2.27)$ & \\
\hline (log) Capital/Employment & $.044 * *$ & $.042 * *$ & $.048 * *$ & & Experience Squared (/100) & & & -.028 & \\
\hline & $(7.78)$ & $(7.63)$ & $(5.07)$ & & & & & $(-1.51)$ & \\
\hline$\%$ Equip $<1 \mathrm{Yr}$ & -.043 & -.033 & .164 & .045 & & & & & \\
\hline & $(-0.78)$ & $(-0.66)$ & $(1.40)$ & $(0.70)$ & --Worker Controls & Yes & Yes & Yes & Yes \\
\hline$\%$ Equip 1-4 Yr & $-.061^{*}$ & -.031 & .033 & .033 & --Recruiting Priorities & Yes & Yes & Yes & Yes \\
\hline & $(-1.73)$ & $(-0.89)$ & $(0.38)$ & $(0.79)$ & --1990 Census Controls & No & No & Yes & No \\
\hline$\%$ Equip $>10 \mathrm{Yr}$ & $.042 *$ & $.044 *$ & $.088^{*}$ & -.059 & & & & & \\
\hline & $(1.85)$ & $(1.96)$ & $(1.81)$ & $(-1.34)$ & R-squared & 0.544 & 0.553 & 0.651 & 0.557 \\
\hline Non-Mfg_\% Equip $<1 \mathrm{Yr}$ & $\begin{array}{c}.095 \\
(1.11)\end{array}$ & & & & $\mathrm{N}$ & 3917 & 2402 & 576 & 1515 \\
\hline
\end{tabular}

Notes

t-statistics in parentheses. Coefficients of percentage variables multiplied by 100 .

All models also include: two-digit industry (\#10 manufacturing, \#11 non-manufacturing) and size (\#5) dummies (coefficients not reported to save space and avoid additional disclosure review analyzes). In the first column, the $\log$ of the capital-employment ratio is set to zero for non-manufacturing establishments. 
Table 1: Variable Descriptions

NOTE TO ARNIE: THIS WORKSHEET DOES NOT PRINT PROPERLY.--I will provide a good hard copy.

\section{PAY, PAY REPORTING AND OVERTIME HOURS}

technical support, (4) office,

following definitions.

WEEKLY, MONTHLY, and ANNUAL: are dummy variables indicating the type of pay reporting (hourly is the left-out category).

OT_HOUR, OT_WEEK, OT_MONTH and OT_ANN: are interactions of the four pay reporting type indicator variables with the overtime share of average usual weekly hours.

If hours, $\mathrm{H}$, are greater than 40 , the overtime hours share is $[\mathrm{H}-40] / \mathrm{H}$; otherwise it is zero.

\section{COMPUTERS}

\% MGR/SUPV COMPUTERS: "What percentage of managers and supervisors use computers in their jobs?"

\% NON-SUPV COMPUTERS: "What percentage of your production and non-supervisory employees use computers in their jobs?"

\section{ORGANIZATION}

\% NON-SUPV IN TEAMS: "What percentage of non-managerial and non-supervisory employees are currently involved in self-managed teams?"

discuss work-related issues?”

TQM: “Has your establishment adopted a formal Total Quality Management program?” This question was asked in the 1994 survey only.

TQM_MISS: Dummy variable equal to one for 1997 observations not part of the 1994-1997 panel.

\% IN JOB ROTATION: "What percent or how many of non-managerial and non-supervisory employees are currently involved in job rotation?"

other organizations'?"

PROFIT SHARING OR STOCK OPT.S: 1997: "Does your establishment contribute toward any of the following employee benefits... stock options or profit sharing" 1994: This

your employees covered by

any of the following [benefits]...stock options."

of this variable plus one.

WKRS-PER-SUPERVISOR: “On average, how many workers report to each front-line supervisor?" [1997 survey adds the interviewer instruction- - “IF NO SUPERVISORS, ASK WITH RESPECT TO FRONT-LINE MANAGERS.”] Regressions use the logarithm of this variable.

\section{INDUSTRY, SIZE CONTROLS}

by the number of

employees in the establishment. The size categories are 20-49, 50-99, 100-249, 250-1,000, >1,000.

\section{FIRM CONTROLS}

MULTI-ESTABLISHMENT FIRM INDICATOR": "Is this the only establishment in your enterprise, or are there others?"

LOG OF CAPITAL STOCK/TOTAL EMPLOYMENT RATIO . For manufacturing establishments, this variable is usually obtained by matching to the Census of Manufacturing for the nearest year-1992 for the 1994 NES and 1997 for the 1997 NES — and then deflating to the appropriate year. If, however, the Census of Manufacturing reports zero capital stock,

the NES report is used instead. For non-manufacturing establishments, this variable is equal to zero.

NON-MFG_EQUIP $<1$ YR, .., $>10$ YR: The four preceding variables interacted with a dummy variable for non-manufacturing. 
PERCENT PRODUCTION/SUPERVISORS: Sum of two responses: "Of your total workforce at this location at the end of 1993 [1996], what percentage were: . . . supervisors? [and] production workers? (Sales/customer service/other front-line workers?)”

PROD/SUPV_\%_97: Above times YEAR 1997 dummy.

\section{EMPLOYEE ATTRIBUTES}

\% FEMALE: “what percent or how many of your employees [1997: “permanent employees”] are women?”

TOTAL WORKFORCE: 1994: The maximum of (i) the response to "How many employees were on your payroll at the end of 1993?" and (ii) the sum of responses to "Of these

employees, how many were (a) full-time, (b) part-time, (c) temporary or contract workers?" 1997: The sum of the responses to "How many contract, leased, or temporary workers

about: (a) permanent full-time,

(b) permanent part-time, (c) temporary or seasonal workers on your payroll.”

\% PART-TIME: One hundred times part-time employment divided by TOTAL EMPLOYMENT.

\% TEMP: One hundred times "temporary or contract" employment [1994], or "contract, leased or temporary" plus "temporary or seasonal" employment [1997], divided by TOTAL EMPLOYMENT.

S' EDUCATION [BY OCCUPATION]: "What is the average number of years of completed schooling for the following categories of employee in your establishment?

(a) managers/professionals, (b) supervisors, (c) technical/technical support, (d) office/clerical/sales/customer service, (e) production employees"

The variable MANAGER/SUPERVISOR EDUCATION is the occupation share weighted average of the first two responses;

PRODUCTION/TECHNICAL EDUCATION is the weighted average of the third and the last.

one year?"

TURNOVER_X_97: TURNOVER PROXY multiplied by the 1997 survey dummy.

UNION MEMBERS: "What percentage of your employees are covered by a collective-bargaining agreement?"

\section{ADDITIONAL MANUFACTURING PRODUCTION EMPLOYEE ATTRIBUTES FROM 1990 CENSUS DATA.}

Production workers are identified using 1990 Census occupation codes. The following are establishment level averages over these workers.

EXPERIENCE: Age minus education minus five.

EXPERIENCE SQUARED: EXPERIENCE squared (squared before averaging).

MARRIED MEN: Male and ever-married dummy variable.

MARRIED WOMEN: Female and married, spouse present dummy variable.

\section{HIRING CONTROLS}

worker (front-line worker), how

considered:...," as follows:

RCRT_EDUCATION: is the sum of responses to three importance-scale items: (i) "years of completed schooling," (ii) "academic performance (grades)," and (iii) "experience or reputation of applicant's school."

applicant's skills).”

RCRT_COMM.SKILL: “Applicant's communication skills.”

RCRT_ATTITUDE: “Applicant's attitude.” 
RCRT_TESTSCORE: "Score received in any tests administered as part of the interview."

In the 1997 survey, the same, or very similar, importance-scale items appear after one or the other of two multi-part questions on recruiting to fill a "typical production employee's job title" (supplied by the respondent) job, referred to as "[JOB TITLE]" in the interviewer instructions. The TESTSCORE item is taken from an item- "Tests administered as part of the interview"-following the first of these questions - "Once you have established a pool of applicants for a(n) [JOB TITLE] opening, what sources of information do you use to evaluate the candidates?...Please use the scale of 1 to 5: (1) Never, (2) Occasionally, (3) Regularly, (4) Often, (5) Always." The other items used to create the above variables for the 1997 survey observations all appear in the next question--“After you have established your applicant pool and obtained information about potential [JOB TITLE] employees, what 